\title{
Heterotopyalar İçinde Bir Birey Nasıl Yaşayabilirr?
}

\section{Arş. Gör. Şeyma Nalan Ekice ${ }^{1 *}$}

Geliş tarihi: 28.08.2019

Kabul tarihi: 27.09.2019

\section{Atıf bilgisi:}

IBAD Sosyal Bilimler Dergisi

Sayı: Özel Sayı Sayfa: $466-485$

Yıl: 2019

This article was checked by iThenticate. Similarity Index 9\%.

\footnotetext{
${ }^{1}$ Eskișehir Osmangazi Üniversitesi Sanat ve Tasarım Fakültesi, Türkiye, sekice@ogu.edu.tr,
}

ORCID ID 0000-0002-9315-6965

* Sorumlu yazar
ÖZ

Michel Foucault, erken döneminde sosyalist ve varoluşçu düşünceden etkilenerek felsefi altyapısını oluşturmuş ve yaşamın nasıl bilim olarak incelenebileceğine odaklanmıştır. Düşünce tarihinde pek yer edinememiş 'aşk, cinsellik, suç ve delilik' gibi konuları filozoftan ziyade adeta bir tarihçi gibi arkeolojik kazıya benzettiği bir düşünüş yöntemiyle detaycılıkla incelemiștir. Foucault, kendisinin icat ettiği 'sorunsallaştırma' tekniği ile yeni bir iktidar anlayışı sunmuş, bilgi ve iktidarın çok yakından ilişkili olduğu sonucuna vararak 'güç/iktidar' mefhumunu yaratmıştır. Ancak, ortaya koyduğu bu kavramla iktidarın tanımını yapmaya çalışmamış, zaten onun tanımlanamaz oluşuna dikkat çekmiştir. İktidarın ne, kim olduğundan çok iktidar etkilerini ve ilişkilerini sorgulamış; bu ilişkisel ağlar içerisinde kontrol mekanizmalarının nasıl çalıştığını ve özneleri nasıl nesneleştirdiğini ortaya koymuştur. Foucault'nun topos'a sosyal ve kültürel farklı boyutlar katarak özne ve iktidar kuramlarıyla ilintili geliştirdiği ve 'gerçekleşen ütopya' şeklinde tanımladığı 'Heterotopya' ise, toplumun kurumsallaşmasında yer alan ötekiliğin gerçek mekanları/uzamlarıdır. Heterotopyalar, öznelerle ve diğer mekanlarla kurdukları ilişkilerle çok fazla çeşitlenirler, dolayısıyla öznelerin nesneleştirilmesiyle alakalı tüm politik, dini, kültürel söylemlerin yaratabileceği ve dönemsel koşullara bağlı da türlerinden bazılarının yok olabileceği ya da yenilerinin eklenebileceği yerler, mekanlar, uzamlardır. 'Bir birey nasıl yaşayabilir?' sorusu ekseninde geliştirilen bu çalışmada, Foucault'nun heterotopyayla ilgili tek kapsamlı açıklama yaptığı 'Of Other Spaces: Utopias and Heterotopias' adlı makalesi baz alınarak heterotopyanın kuramsal çerçevesi tanıtılacak, heterotopya türleri incelenecek ve yorumlanacaktır.

Anahtar Kelimeler: Michel Foucault, Ütopya, Heterotopya, Özne, İktidar. 


\section{How can an Individual Live in Heterotopias?}

\section{Res. Assist. Şeyma Nalan Ekice ${ }^{1^{*}}$}

First received: 28.08 .2019

Accepted: 27.09.2019

\section{Citation:}

IBAD Journal of Social Sciences

Issue: Special Issue Pages: 466-485

Year: 2019

This article was checked by iThenticate. Similarity Index 9\%.

1 Eskisehir Osmangazi University, The Faculty of Art and Design, Turkey, sekice@ogu.edu.tr,

ORCID ID 0000-0002-9315-6965

\section{* Corresponding Author}

\begin{abstract}
Foucault formed his philosophical infrastructure by being influenced by socialist and existentialist ideas in his early period, and focused on how life can be studied as science. He examined subjects such as 'love, sexuality, crime and madness' which had not attracted much attention in the history of thought, with a method of thinking which he likened to archaeological excavations like a historian rather than a philosopher. Foucault introduced a new understanding of power with the 'problematization' technique he invented, and created the concept of 'power / knowledge' asserting that knowledge and power are very closely related. However, he did not try to define power by this concept, but he already pointed out that it is unidentifiable. He questioned power effects and relations rather than what or who power is and elicited how control mechanisms work and how they objectify subjects in these relational networks. When it comes to 'Heterotopia', which Foucault developed in relation to subject and power theories by adding different social and cultural dimensions to topos and which he defined as 'realized utopia', these are the real spaces/places of otherness that take place in the institutionalization of society. Heterotopias are highly diversified by their relationships with subjects and other places, and therefore, they are places, spaces, where all political, religious, cultural discourses related to the objectification of subjects can be created and where some of their species may be disappeared or replaced by new ones depending on the periodic conditions. In this study conducted around the question of 'How can an individual live?' the theoretical framework of heterotopia will be introduced and the types of heterotopia will be examined and elaborated based on Foucault's article entitled 'Of Other Spaces: Utopias and Heterotopias' which is his only comprehensive study about Heterotopia.
\end{abstract}

Keywords: Michel Foucault, Utopia, Heterotopia, Subject, Power. 


\section{GİRIŞ}

Bir bebek doğduktan sonra neden ağlar? Genelgeçer bir ifadeyle bebeğin ilk nefes alışının teyiti olarak bilinir. Oysaki bebeğin sudan karaya geçiş sürecine doğru gerçekleşen simbiyotik ilişkinin bitiminin göstergesidir. Plasentada bir kordonla annenin akciğerlerini paylaşan canlının artık tek başına tanışık olmadığı bir yerde nefes alma çabasıdır. Bir ritüelmiş gibi vuku bulan bu biyolojik vaka, aynı zamanda varoluşun en kısa aforizmasını sunar: sade bir çığlık. Böylelikle, canlının uzam değiştirmesine yönelik verdiği tepki de denilebilir ki bebeğin farklı bir uzama geçmesi, onun için bir yabancılaşma yaratır. Sudan karaya geçişteki yabancılaşma ise topos'la oluşacak yeni bir bağın kurulmasıyla sonlanır. Tarihler boyunca, kara varlıklarının en hegemonyacısı olan insanlar, birey oluşunu toprak parçası ile imlemiş ve bununla ilintili bir şekilde antikitenin topos, polis gibi sözcüklerini çağın modern ve hatta postmodern hayatlarına uyarlama hassasiyetiyle mekan ve uzama olan bağl1lı̆̆ını perçinlemiştir.

İnsanların uzama duydukları bağlanma arzusunun kaynağı ve topos'un bebeklik dönemlerinden itibaren benimsenmesinin nedeni ontolojik ve psikanalitik açıdan da değerlendirilmektedir. Şöyle ki, psikanalitik analizlerini cinsellik ve bilinçdışı ${ }^{1}$ söylemleriyle bütünleştiren Freud'un kuramlarını geliştirerek onlara daha çok sosyokültürel bir boyut kazandıran Jacques Lacan'ın 'Ayna Evresi' günümüzde politik ve sosyolojik bir boyuta da ulaşmış yere özgü olma durumunu açılayan ünik bir kuramdır. Lacan, Freud'un arzu üzerine temellendirerek yaptığı insan tanımını, doğa ve kültür ilişkisi içinde yeniden ele alır. Freud'a göre, sadece ilkel dürtülerden oluşan biyolojik bir varlık olarak görülen insan, Lacan'da kültürel bir kimlik kazanır. Freud, kişiliğin id, ego ve süperego olmak üzere üç katmandan oluştuğunu söyler; İd'de bebek, daha yeni doğduğu için bilinçli hiçbir süreç yaşamaz ve sadece hazları (yeme, içme, uyku) vardır ve bunları karşılama gereksinimi içindedir (Tura, 2017, s. 59). İd'in oedipal dönemi ${ }^{3}$ atlatmasıyla ego oluşur, egonun karşıllığ ise Lacan'da öznedir. Lacan'ın ego yerine özneyi kullanması, insanı toplumsal bir varlık olarak görmesinden kaynaklanır. Bu yüzden de, Freud'dan farklı bir şekilde kişilik oluşumunu üç evrede inceler. Bunlardan ilki, bebeğin kendisinin özne olarak farkında olmadığı ve hayali bir uzamda yaşadığı İmajiner dönemdir (Başer, 2012, s. 65-66), (Başer, 2012, s. 131). Lacan, bu dönemi bir özdeşleşme ${ }^{4}$ olarak tanımladığı 'Ayna Evresi' üzerinden açıklar: öznelliğin ilk basamağına referans veren bu evre, bir bebeğin uzamla kurduğu bütünlük/parçalılık ilişkisine dayalıdır. Şöyle ki, altı-on sekiz aylık bir periyottaki bebeğin çevreden alımladığı hareketleri benimseyerek onları tekrar ve taklit etmesiyle ben'i oluşur. Yani, ilk başta kendi beden hareketleri ve dışsal tüm uyaranlarla birlikte bebek, kendini bir bütün olarak hisseder. Ancak, bir aynanın önünde insani ya da yapay bir destek yardımıyla bir an için kımıldamadan durduğunda bebek, kendi kimliğinin inşasına başlamaktadır (Başer, 2012, s. 113). Çünkü artık onun dışında kalan tüm kişi

\footnotetext{
${ }^{1}$ Freud, insan psişenin bilinçaltı ve bilinçdışından oluştuğunu söyler. Bilinçdışı, tamamen bilincin alanının dışında ve ulaşılması zor simgesel bir yerdir. Freud'a göre, bilinçdışı bir tür savunma mekanizması gibi çalışır ve burada toplumca kabul görmeyen cinsel arzu ve dürtüler bastırılır. Buna karşılık bilinçaltı, dikkatin yoğunlaştırılamadığ algıları, otomatik hareketleri, fikir çağrışımlarını, hatta üzerinde bilinçli olarak düşünülmediği halde bir anda olgunlaşmış olarak bilinç alanında bulunan fikirleri ilgilendirir. Kaynak için bk. Tura, 2017, s.53.

2 Lacan, ‘Ayna Evresi'ni ilk kez 1936'da Uluslararası Psikanaliz Kongresi'nde sunar ama kongrede süre kısıtlamasına takılınca konuşmasını yarıda bırakmak zorunda kalır. Bu yüzden, 1936 tarihli metnin kaybolduğu ileri sürülür. Lacan, on yıl sonra konuyu yeniden ele aldığında değişik bir metin hazırlar ve bu metni Zürih’te 17 Temmuz 1949'da yapılan 16. Psikanaliz Kongresi'nde sunar. Kaynak için bk. Başer, 2012, s.112.

${ }^{3}$ Thebes Kralı Oedipus'un babasını öldürüp annesiyle evlendiği miti anlatan Yunan tragedyasından ismini alan Oedipal dönem yani, Oedipus Kompleksi, kız çocukların babaya, erkek çocukların da anneye yönelik libidinal dürtüler beslemesidir. 'Ayrıca, kastrasyon karmaşasının da yaşandı̆̆ bu dönemde, kız çocuk kastre edildiği fantezileriyle, yani eskiden sahip olduğu bir penisin ondan alındı̆̆ imgelemesiyle, penis sahibi olmak yerine babasından bir çocuk sahibi olmayı düşler ve böylece libidosunu babaya yöneltirken, erkek çocuk annesine duyduğu cinsel arzular nedeniyle babası karşısında geliştirdiği saldırgan duyguları babasına yansıtır ve babası tarafindan penisi kesilmek suretiyle cezalandırılacă̆ kaygısına kapılır. Karmaşanın çözümü, erkek çocuğun annesinden vazgeçmesi (ensest yasağını tanıması) ve babasıyla özdeşleşmesi iken, benzeri süreç klzlarda çok daha geç ve güç gerçekleşir.' Kaynak için bk. Tura, 2017, s. 57-58.

${ }^{4}$ Lacan, özdeşleşmeyi (identification) öznede bir hayali benimsediği zaman ortaya çıkan bir değişiklik olarak tanımlar ve bu yüzden ‘Ayna Evresi’nin bir özdeşleşme olduğunu söyler. Kaynak için bk. Başer, 2012, s.113. Saffet Murat Tura ise, identification kelimesinin analitik bağlamdaki anlamının Türkçe'de ancak 'özdeşleşme-kimlik kazanma' kavram çifti ile karşılanabileceğini dile getirir. Kaynak için bk. Tura, 2017, s. 18.
} 
ve nesneler parçalı, ayrıksı ve ona ait değildir. Bebek hem aynayla hem de yerle kurduğu ilişkiyle ilk kez tutarlı bir kimlik deneyimi yaşar. Böylelikle, Lacan'ın psikanalitik anlatısına göre, uzamın insana içkin olarak bir özbenlik oluşturmasındaki rolü kavranabilir.

Lacan'ın diğer evreleri ise 'Sembolik Evre' ve 'Gerçek Evre'dir (Başer, 2012, s. 84), (Başer, 2012, s. 131, 132), Aslında, ayna evresi tamamlandıktan sonra sembolik evre başlamaz, çünkü sembolik evre ayna evresini de içinde barındırır. Gerçek evre de sembolik evrenin dilsel araçlarıyla ilişki içindedir. Dolayısıyla, Lacan'ın psikanaliz modelindeki deneyim alanı bu üç evrenin birlikte işlemesiyle oluşur. Gerçeklik ilkesinde açık gerçekler yoktur; çünkü Lacan'a göre, insan 'olmakta' eksik olan bir varlıktır, bu yüzden de simgelerin ailenin oedipal yapısına bağladığı kültürel bir gerçeklik vardır. İnsan gerçekliği de dilin yapısının imkanları ve kuralları ile düşünebilen bir gerçekliktir (Tura, 2017, s. 172) Dolayısıyla, dil gerçekliği yeniden yaratır ve öznenin gerçeklikle, kendisi ile ötekilerle olan ilişkisini düzenler, yani dille birlikte toplumsal yasalar ortaya çıkar (Tura, 2017, s. 176-177). Bu yüzden, Lacan'a göre özne, yasalar ve buyrukları içselleștirir, yani yasaları hazır olarak bulan özneler bunları direkt bir şekilde uygulamaya başlar. (Tura, 2017, s. 177-178). Çünkü bir bebeğin dil edinimi de hazır bir şekilde ailenin söylemiyle gerçekleşir ve bebek konuşmaya başladığı anda toplumsal normlar gibi dili de içselleştirir (Tura, 2017, s. 80). Lacan, sembolik evrede bebeğin dili öğrenmeye başladığını ve ancak dil beceresi kazandığında bebeğin kendisini anneden tamamıyla ayırabildiğini söyler. Ayrıca, Freud'un oedipus kompleksinde yasa koyucu baba figürüne karşın, Lacan sistemin ögelerinin dil edinimiyle birlikte içselleştirildiğini dile getirir. Dolayısıyla Lacan'ın psikanalik çözümlemesinde baba figürü önemli bir yer teşkil etmez, onun için geçerli olan babanın yasa ve kurallarıdır. Bu yüzden de, baba yerine 'babanın adları'nı kullanarak baba adının babayla sınırlandırılamaz oluşuna dikkat çeker, çünkü kültür ve toplumla ilgili olarak özneleri tahakküm altına alan her şey 'Baba-nın-adları' olarak nitelendirilebilir (Lacan, 2017, s. 80-81). Bununla birlikte, ilk başta dünyanın tüm bütünlügüule birlikte kendini imgeler bütünü olarak gören bebeğin ayna evresinde benliğini kazanmaya başlamasından sonra da dilin simgeler yoluyla edinimiyle bilinçdışı oluşur. Bu yüzden, Lacan'a göre bilinçdışı, saf dürtülerin bastırıldığı bir yer olmaktan çıkarak toplumun oluşturduğu simgelerin bastırıldığı bir yere dönüşür (Tura, 2017, s. 67-68). Ayrıca, ayna evresinde imge bütünlüğünden simge alımlamalarına geçen bebek, bu şekilde sadece ilk kez kimlik deneyimi yaşamış olur, oysa tamamıyla anneden ayrılarak kişisel benliğini kazanması, oedipus'a girdiği zaman yani, dil edinimiyle gerçekleşir (Tura, 2017, s. 80).

Peki, benlik ve bilinç kazanımı sonrasındaki bir birey nasıl yaşamaya devam eder? Todd May, bir Deleuze incelemesi olarak yazdığı ayrıca Nietzsche, Derrida ve Foucault'nun ontolojik yaklaşımlarına yer verdiği 'Bir birey nasıl yaşayabilir?' adlı kitabının ilk bölümünde bu sorunun tarihsel çizgi içerisindeki varyasyonlarını cevaplandırmıştır. Yine, uzamın sosyolojik ve politik etkilerine göre değişim gösteren bu soru, antikitede 'Bir birey nasıl yaşamalıdır?' şeklinde sorulmuştur. Bu sorunun antik temsilcisi Sokrates, yaşamı formlaştırıp bir bütün şeklinde ele alır, dolayısıyla evrenin düzenine uyum sağlayan rotaların ne olduğu, nasıl planlanması gerekliliği önem taşır. Platon ${ }^{5}$ da hocasının sorusunu değiştirmeksizin 'iyi'ye dayalı toplumsal düzeni savunur. Aristoteles ise tüm evrenbilimsel metodoloji içinde erekselliği ön plana çıkarır. Üç filozofun ortak paydası ise, metaforik anlamda 'bedensiz organ' olamayacağı yönündedir (Platon, 2010, s. 143). Yani, bir insanın organının beden dışında yaşamayacağına koşut, bir bireyin toplumsuz kendi başına bir fayda sağlayamayacağı savı geçerli kılınır. Böylelikle, evrenin düzenine göre fiziki olarak farklı topos'lara sahip bireylerin ekonomik ve politik statüleri de birbirinden farklılaşır. Örneğin, Sokrates zamanındaki demokrasi rejiminin hocasının haksız infazı gerekçesiyle adaleti sağlamadığı görüşünde olan Platon, aristokratik yönetim biçimini desteklemiştir (Platon, 2010, 562/a, s. 291). Sokrates'in 'İyiler mutludur' (Platon, 2010, 354/e, s. 39) şeklindeki ahlaki erdemlerle ve yüce gönüllüğüyle içselleştirdiği anekdotuna karşılık, Platon 'yalnızca adaletsizler mutsuzdur' (Platon, 2010, 578/c, s. 313) deyimiyle eğitime öncelik tanıdığı siyasi bir model benimsemiştir. Platon işçiler, bekçiler ve yöneticilerden oluşan ideal devlet anlayışında filozof-kral mefhumunu öne sürerek, yönetimsel kabiliyetin sadece akıl, adalet ve

\footnotetext{
5 Platon, ideal devlet anlayışında aristokrasiyi savunmasıyla demokrasiye karşı çıkar. 'Ayrıca, Platon'a göre, çocuklar doğduktan kısa bir süre sonra ĕgitim almak amacıyla annelerinin yanından ayrlmalıydl. Çocukları, aileleri değil; kurul yetiştirecekti ve böylece aileye değil, devlete ait olacaklardı.' Kaynak için bk. Platon, 2010, s. 164.
} 
bilgi yetisine sahip filozoflarda bulunduğunu savunmuştur. (Platon, 2010, 485/b-485/d s. 194, 195). Kısacası, antik dünyada yaşayan canlı bir organizma gibi görülen evrenin formlaşarak devasa bir bütün oluşturmasına dayalı geliştirilen toplumsal düzen, ancak hiyerarşi ile sağlanabilir. Dolayısıyla da, farklı statülere sahip bireylerin her biri yukarısındaki tarafından tahakküm altına alınmak zorundadır. Evrenin ve ögelerinin ezici üstünlüğ̈̈ karşısında bir filozof-kral bile zorundalık kipinde yaşamalıdır; bu evrenbilimsel düzenin kaçınılmaz sonucudur (May, 2017, s. 18).

Antik çağlarda ahlaksal ve ussal değerler merkezli yaşamdan sonra Ortaçağ'da hakim olan ideoloji ise dini inançlara göre düzenlenen varoluşsal normlar bazındaki yaşamsallığın kutsandığı dogmatizmdir. Oysaki bizim karanlık dönem diye atfettiğimiz Ortaçağ, Yunan ve Roma öğreti ve inanışlarından farklı bir yenilenme kaydettiği için kendini 'modernus' ilan etmiştir. İlk modernler şeklinde tanımlanmalarına neden olan da paganizmden ayrı bir uzamda sonsuz yaşamı keşfetmiş olmalarıdır. Yani, tek gerçeğin ulvi yaşam olduğu bu dönemde insanın dünyevi hayatına dair sorgulama yapmanın mantığını aramak nafiledir. Daha yakın döneme ait diyebileceğimiz bize aşina gelen modernizmin neyi sorduğuna bakacak olursak, artık insan eylemlerinden mütevellit bir varlık konumundadır; öyleyse 'Bir kişi nasıl eylemelidir?'. Immanuel Kant ve Jeremy Bentham gibi filozofların 18. yüzyıl sonlarında gündeme getirdiği bu yeni soru, ilk başta eskisiyle (antik soruyla) aynı gibi görülebilir (May, 2017, s. 17). Çünkü kişinin eylemlerinin yaşamını belirleyen kıstaslar olduğu şeklindeki düşünce hala yoğun bir şekilde kabul görmektedir. Ancak, burada kastedilen artık evrenin bütününe (yaşamın bir bütün olarak ele alındığı) uyum sağlama zorunluğunun ortadan kalkmasıdır. Bireyin salt gerçekliği, evrenin bütünsel düzeninden özerk, yani tüm insani değerlerin tek bir çatı altında toplandığı nesnellikten öteye geçmektedir. Kişi hak ve özgürlüklerinin temelinde yatan da modernizmin sunduğu bireyselliktir. İnsanın kendi öz değer ve inanışlarına bağlı yaşam sürebilmesi eylemlerinin niteliğini tayin edemez, dolayısıyla farklı eylemlerle özdeşen modern yaşam farklı özneler ${ }^{6}$ yaratma temayülündedir.

Her ne kadar evrenin bütüncüllüğüne yönelik ilginin azalması, bazı filozoflarca düşünce sisteminde açılan büyük bir boşluk manası taşısa da, bireyciliğin yükselişiyle eşitsizliğin ortadan kalktığına inananlar da olmuştur. Çünkü artık felsefe kim olduğumuz veya nasıl olmamız gerektiğiyle ilgili saptamalar yapıp yasalar koymamalı; insanın kim olduğu meselesi, sadece o şahsın özel sorunsalı olmalıydı. Böylelikle, eylemlerinden sorumlu olan her farklı öznenin yükümlülükleri de farklılaşırken, artık onları doğru şekilde yerine getirme vazifesi söz konusu olacaktı. Ancak vazifeler, ödevler, yükümlülükler doğası gereği edilgen değildir ve şeylere karşı yerine getirilir. Dolayısıyla, insanın eylemine vurgu yapan bu modern sorunun cevaplanmasına yardımcı olacak ölçütlerin aşkınlığı, aynı zamanda antikiteyle olan bağın tamamen kopmadığına referans verir. Bu soruyu cevaplayan filozofların odak noktasında da sadece toplumsal görevlerin yer almadığı gibi bu yükümlülüklerimizi teminat altına alan bir Tanrı'nın varlığıyla temellendirilen yüce ahlaki yasa ve ilkeler vardır. Bununla beraber, antikitenin evrenbilimsel düzeninin modernitenin eylemlerimizi tayin eden aşkınsallığından pek de farklı olmadığı minvalinde yeni bir soru daha doğmuştur: 'Bir birey nasıl yaşayabilir?' Aslında bugün hala sorulan bu sorunun kökleri, Nietzsche'nin 19. yüzyılda içinde yaşadığı döneme dayanır. Bu soruyu sorduran ise Nietzsche'nin en bilinen mefhumlarından olan 'Tanrı'nın Ölümü'dür. Nietzsche'ye göre, geç 19. yüzyılın merkezi olayı, Tanrı'nın ölümüdür ve nasıl eyleceğimizle ilgili soru, Tanrı'nın ölümünden önceki dönemin kalıntısıdır: bir arkaizm, bir nostaljidir. (May, 2017, s. 21). Nietzsche'nin gerçekten Tanrı'yı öldürüp öldürmediği hala tartışadurulsun, onun asıl ereğinin yasa koyuculara meydan okuma olduğu salt bir gerçektir.

Bireyler belirli bir sınırlar kategorisinde yaşamaya mahkum edilmiş varlıklar olarak takdim edilen görevleri bir bir yerine getirirken ya da tam tersine getiremedikleri için kendilerini cezalandırırken bir o kadar da kendileriyle yabancılaşma riski altındadırlar. Çünkü yapabilecekleriyle değil, yapamadıklarıyla kendilerini tanımlamaya meylederek, herkes gibi yaşamanın hülyası içinde kaybolmaya sürüklenmişlerdir. Bu yüzden de, saf dışı bırakılmamak adına stereotipleştirilmiş hayatları seçmenin kolaycılığına kaçarken, kendilerini kurtarmanın yollarını, ya geçmiş toplumsal bağlarda ya da geleceği inşa edeceğine inandıkları liderlerde aramakta bulmuşlardır. Böylelikle, birey kendi özünden başka her yerde her kimsede deva ararken, 20. yüzyıl Kıta felsefesinin büyük bir bölümü, bu yaşamsal

\footnotetext{
6 'Farklı özneler' bir olumlama gibi görünse de, modernizmin meydana getirdiği sınıf çatışmasına bir gönderme niteliği taşır.
} 
derdi meydana getiren toplumsal yapıları, siyasi otoriteleri, kültürel kodları konu edinmiş, gerçeği ifşa etme yolları aramıştır.

'Bir birey nasıl yaşayabilir?' sorusu, yeti ve edinimle ilişkilidir; hem bireyi küçültür, hem de bireyi yüceltir. Çünkü ancak dışsal ve çevresel koşullara karşı yetisi olanlar uyarıcıların etkisini azaltarak yaşayabilir, yetisi olmayanlar da yaşayamaz. Uyarıcıların bolluğunda yaşam, artık bir kaosa; yaşamak ise bir edinime dönüşmüştür. Ayrıca, yaşam kendi içinde kontrol mekanizmaları inşa etmiş ve kontrol ettiği, gözetiminde bulundurduğu her öznede sıkışma, maruz bırakma, etkileme ve sürükleme gibi fenomenler yaratmıştır. Ancak, modernizm öncesi öznellik ve bireysellik gibi kavramların adı bile geçmediği için yaşamın birey üzerindeki etkisi dikkate alınmamıştır. Sonrasında ise, Sanayi Devrimi'yle birlikte üretimin ve iş bölümünün artması neticesinde yeni bir yerleşim ve yaşam düzenine geçişin sembolü haline gelen kentleşme, bireyleri ilk başta ekonomik bir şekilde etkilese de; günümüze kadar güncelliğini koruyan en büyük etkisini politik ve psikolojik bağlamda sürdürmüştür. Böylece, gerçekten de bu değişim ve dönüşümün yaşandığı dönem olarak Nietzsche'nin 19. yüzyıl sav1 doğruluğunu ve geçerliliğini korumaktadır. Bununla birlikte Deleuze, Guattari, Derrida gibi birçok kuramcı da bu yeni mekânsal dekoru, içindeki figürlerle birlikte incelemiştir. Ancak, bu çalışmada 'Bir birey nasıl yaşayabilir?' sorusunu destekleyen en önemli düşünür Foucault'dur, dolayısıyla Foucault'nun güç, bilgi ve özne kavramlarıyla ilişkili geliştirdiği iktidar mekanizmaları ve heterotopya kuramı çalışmanın merkezini oluşturmaktadır. Sorulan bu soru ise, sosyolojik ve siyasi boyutlarda tahakküm altında kalan öznelerin eylemlerinin ve toplumsal ve kültürel düzendeki davranış biçimlerinin Foucault çerçevesinden incelenmesi ve tartışılması için metaforik bir anlamda kullanılmıştır. Bu yüzden de, çalışma özellikle Foucault'nun heterotopya kavramını odak noktası almış ve heterotopyanın Foucault'nun ürettiği bir kavram olması dolayısıyla da onun bu konu hakkındaki tek kapsamlı çalışması olan 'Of Other Spaces: Utopias and Heterotopias' adlı makale İngilizceden çevrilerek incelenmeye alınmıştır. Çalışma için yapılan araştırmalar ve analizler sonucunda ise Foucault'nun iktidar mekanizmaları ile heterotopya kavramlarının birbiriyle yakından ilişkili olduğu tespit edilmiş ve bu yüzden de Foucault'nun iktidar mekanizmaları ile ilgili birincil kaynaklardan yararlanılmıştır. Ayrıca, bu iki önemli kuram arasındaki farklar ve benzerlikler 'Heterotopyalar İçinde Bir Birey Nasıl Yaşayabilir' sorusunun sorulmasına kaynaklık etmiş ve her iki kuramın karşılaştırılmasına dayalı ortaya çıkan sosyokültürel dinamiklerin soruyla doğrudan ilişki kurduğu gözlemlenmiştir. Şu ana kadar heterotopya ile ilgili pek fazla çalışma ve yayın yapılmamış olmakla birlikte yapılan bazı araştırmalarda ve yazılan bazı tezlerde de heterotopya kavramı genellikle görsel çözümlemeler ve mimari alanlar üzerinden açıklanmaya çalışılmıştır. Bu yüzden, bu çalışma konu özelinde heterotopya kavramının doğru anlaşılabilmesi ve genelinde ise heterotopyanın Foucault'nun düşünce sistemindeki yeri ve önemini açıklamak ve tartışmak üzere yapılmıştır.

\section{FOUCAULT TARIHHELLİ̆İ VE ÖTEKILİĞIN UZAMLARI}

Ütopya ve heterotopya, Antik Yunanca 'yer/toprak/ülke' anlamına gelen 'topos'tan türeyerek günümüze uyarlanan sözcüklerdendir. Ütopya köken olarak 'yok/olmayan' anlamına gelen 'ou'; 'mükemmel' anlamındaki 'eu' ve daha öncede değinilen 'topos' sözcüklerinin birleşiminden oluşmuştur. Platon'un ideal devlet anlayışından esintiler taşıyan İngiliz yazar Thomas More'un aynı şekilde ideal bir toplumu konu edindiği 1516 tarihli 'Ütopya' adlı romanının yayımlanmasından sonra yaygın bir şekilde kullanılmaya başlamıştır. Biraz alegorik biraz da sürreal düşüncelerle ve kullanılan figürlere de serbestlik tanıyarak 'hayali, istenen ve arzulanan bir toplum, devlet ve dünya düzeni tanımlarıyla' olumlu çağrışımlarda bulunan ütopyalar özellikle, sosyalist devrimcilerin ereğini yansıtan temel ideolojilerdendir. Örneğin, Fransız sosyalizmin kurucusu Claude Henri de Saint Simon, dünyayı daha iyi bir yer hale getirme inancını ütopik düşünceyle şekillendirmiş ve hatta onun etkisiyle çevresindekiler de ütopik sanat fikrini ortaya çıkarmışlardır.

Hetorotopyanın etimolojisi ise 'diğer/başka/farklı' anlamındaki Antik Yunanca 'heteros' ön ekine 'topos'un eklemlenmesiyle açıklanabilir. Böylelikle, heterotopyanın Türkçe'deki karşılıkları 'diğer yer', 'başka/öteki yer', 'farklı yer' sözcükleridir. Heterotopya, her ne kadar ötekiliğe dair mekanı çağrıştıran bir terim olsa da, ilk kez tıbbi anlamda kullanılmıştır. Tıp literatüründe, '(1) Bir organ veya oluşumun normal yeri dışında bulunuşu; (2) Herhangi bir dokunun normalde bulunmaması gereken bir yerde gelişmesi' (https://saglik.sozlugu.org/heterotopia/ Erişim tarihi: 01.07.2019) şeklinde 
geçmektedir. Bu şekilde, 'yere' özgü bir olumsuzluk anlamı taşısa da, yine de 'yere' vurgu yapması dolayısıyla kavramın, tıp dışında özellikle mimarlık ve şehir planlama alanlarında kullanılmasına yol açmıştır. More'un ütopyası gibi bu kelimeyi felsefi boyutta ilk kez kullanıma açan ve yaygınlık kazanmasını sağlayan kişi ise ünlü filozof Michel Foucault'dur. 1966 yılında yayımlanan 'Kelimeler ve Şeyler' adlı kitabında ilk kez bu terimden bahseden Foucault, daha sonra 14 Mart 1967 tarihinde mimarlara yönelik verdiği konferansta terimin kapsamlı bir açıklamasını yapmıştır. Ancak, bu konferans metninin uzun bir süre yayınına izin vermezken sonrasında 'Architecture, Mouvement, Continuité' adlı derginin Ekim 1984 sayısında yayımlanmasına ikna olmuştur (Foucault, 2014, s. 291). 'Des Espaces Autres' adlı Fransızca asıl metinden iki yıl sonra 'Of Other Spaces' adiyla İngilizce'ye çevrilmiş ve 2000 yılında da 'Başka Mekanlara Dair' başlığıyla Türkçe olarak yayımlanmıştır (Foucault, 2014, s. 291-302).

Foucault'nun temel referansları Kant, Nietzsche ve Marx gibi birbirinden farklı minvalde çeşitli düşünürler olmasına rağmen, kimi zaman Foucault'nun 'epistemi'si, Kant'ın 'a priori' kavramının geliştirilmiş hali olarak görülmüş ya da Foucault'nun 'insanın ölümü' söylemi, Nietzsche'nin 'üst insan' modeli gibi algılanmıştır. Bu kavram karmaşası ve yanlış okumalar yüzünden de, Foucault bazen faşist bazen de marksist olarak atfedilmiş̧ir. Oysaki yaşamın bilim olarak incelenebileceğini odak noktasına alan Foucault, 'sorunsallaştırma' tekniğini bilgi, iktidar ve cinsellik mefhumlarıyla kurduğu üçleme üzerinde kullanmıştır. Foucault, sorunsallaştırmayı tarihin belli dönemlerinde bazı şeylerin sorun haline getirilmesi şeklinde ele alıp (Foucault, 2015, s. 15); cinselliğin, deliliğin, cezanın ve cezalandırmanın (suçun) tarihini esasında normal/anormal, akıl/akılsız, suçlu/iyi çocuk gibi diyalektikler bağlamında yazmıştır. Aslında bir şekilde tarihin ve insanın mutasyona uğradığını belirtmiş ve heterotopya kavramının ilk kez geçtiği 'Kelimeler ve Şeyler: İnsan Bilimlerinin Bir Arkeolojisi (1966)' kitabının ana sorunsalını da 'insan biçiminin ortadan kalkmasının dünyanın sonunun geleceğine eşdeğer olmadığını gösterebilmek' (Akay, 2016, s. 94) şeklinde belirtmiştir. Ayrıca, bu kitabın Arjantinli yazar Jorge Luis Borges'in Çin Ansiklopedisinden yaptığı bir alıntıdan esinle doğduğunu da ekleyerek hayvanların sinıflandırıldığı bu metni, kitabının önsözünde şöyle paylaşmıştır: 'a) İmparatora ait olanlar, b) İçi saman doldurulmuş olanlar, c) Evcilleştirilmiş olanlar, d) Süt domuzları olanlar, e) Deniz kızı gibi olanlar, f) Masalsı Hayvanlar, g) Özgür köpekler, h) Bu tasnife dahil olanlar, i) Deli gibi çırpınanlar, j) Sayılamayacak kadar çok olanlar, k) Deve tüyünden yapılı ince bir firça ile resmedilenler, I) vesaire, m) Testiyi kırmış olanlar, n) Uzaktan sineklere benzeyenler' (Foucault, 2001).

Kitabın giriş bölümünde tuhaf addedilebilecek bu sınıflandırma herhangi bir mantıksal dizime sahip değilmiş gibi gözükse de, Foucault'nun asıl dikkat çektiği kültürel değerlerin bazı tesadüfi düzenlemeler inşa edebileceğidir. $\mathrm{Bu}$ yüzden, kendisi tarihin kültürel ve sosyolojik boşluklarının kapanmadan anlaşılamayacağını; aşk, cinsellik, suç ve ceza gibi konuların araştırılıp dahil edilmesiyle toplumsal yapının ve iktidar kaymalarının değişimi hakkında bilgi edinebileceğini savunmuştur. $\mathrm{Bu}$ şekilde, belirli bir tarihsel döneme özgü bilgi yapısını gün yüzüne çıkarma anlamında arkeoloji terimini ve yine belli bir çağın düşünce yapısının şekillendirdiği ve varsayımlar ile önyargılar oluşturduğu bilme yöntemi için de epistem terimini kullanmıştır (Foucault, 2016, s. 9). Yukarıdaki örnekte görülen tasnif de Çin'in sadece belirli bir dönemine özgü zihniyetinin ve kültürel fenomenlerinin ürünü olarak ortaya çıkmışıı. Dolayısıyla, bir dönemin yaşantısını, sınırlarını, bilgi dağarcığı ile hakikat anlayışının tümünü kapsayarak bilgi edinme metodu olan epistem, aynı zamanda Foucault tarihselliğinin nasıl işlediğine dair de ipucu verir. Onun tarihsel anlatısı, birbiri üzerine eklemlenen ve böylece sürekli gelişim gösteren, ilerleyen büyük çizgisel yapılar barındırmaz: İnsan ve yaşamı tarihler boyunca mutasyona uğramış, bazen bütüncül evren arayışında merkez noktalar belirlemiş bazen de merkez noktasını kaybederek süreksizlik girdabına kapılmıştır. Foucault'nun tarihi söylemi ile bilgi ve iktidarın iç içeliği durumu, onun heterotopyalarının anlaşılması için önemlidir. Bundan hareketle onun özneye ve mekana

\footnotetext{
${ }^{7}$ Metnin orijinal başlığından yola çıkılarak 'espace' ve İngilizce metindeki 'space' kelimelerinin mekan dışında uzay, uzam, boşluk ve aralık anlamları taşıdığı da bilinmektedir. Her ne kadar bu metnin Fransızca ve İngilizce başlıklarındaki ilgili kelimeler Türkçe’ye mekan olarak çevrilse de, İngilizce metnin tarafimca tekrar çevrilmesi sonucunda konuyla bütünlüğü açısından mekan yerine uzam tanımının yapılmasının doğru olacağı görüşündeyim.
} 
dair geliştirdiği kavramlarıyla altı ilkede özetlediği heterotopyalarının yorumlanmasında, Borges'in Çin ansiklopedisi alıntısını aklımızın bir köşesinde tutmakta fayda vardır.

\section{FOUCAULT'NUN ÜTOPİK VE HETEROTOPİK UZAMLARI}

Foucault 'Of Other Spaces: Utopias and Heterotopias' başlıklı yazısına, 19. yüzyılın en büyük saplantısının tarih olduğunu söyleyerek bir girizgah yapar, 19. yüzyılda gerçekleşen olayları ekonomik durgunluk ve ivmeyle ilintili duraklama ve gelişme temaları, sürekli birikmiş geçmişin temaları, hastalıklardan dolayı ölümlerin aşırı artması ve buzullaşma gibi örneklerle açıklayarak yine o dönemin epistemi hakkında bilgi verir. Devamında yaşadığımız çağın ise uzam ${ }^{8}$ dönemi olarak tanımlanabileceğine değinir (Foucault, 2014, s. 291). Burada, 19. yüzyılın tarihselliği yine Nietzsche'nin Tanrı'nın ölümüne referans verdiği dönemle özdeşleşir ve aynı şekilde Foucault da 19. yüzyıla kadar insan diye bir şey olmadığını iddia eder. Ona göre, klasik epistem (Rönesans episteminden sonraki Akıl Çağı Epistemi) akla dayalı deney ve gözlemlerle gerçekleştirilse de nesnenin ön planda olduğu ve gözlemci olan öznenin de nesneleştirildiği bir bilgi rejimidir. Ancak, 19. yüzyıla gelindiğinde insanın tarihsel bir konu olarak ele alınmasının güç ilişkilerinden kaynaklandığını da ilave eder. Şöyle ki, aşkınlık ve içkinlik mefhumlarıyla ilintili bir şekilde Klasik Çağ insanının içindeki güçler ile dışındaki güçlerin birleşimden bir biçimde vücut bulduğu söylenebilir. Foucault'nun yukarıda da bahsi geçen 'insan biçimi'nin değişmesinin manası, onu meydana getiren bileşimlerin ve güçlerin yeni başka bir form oluşturmasıdır. Foucault, dıș güçleri genellikle, toplumsal ve tarihsel olușumların etkisi altında şekillenen iktidar mekanizmaları olarak açıklarken, 17. yüzyıl insanının içsel ve dışsal iki bileşimi Tanrı fikrini; 19. yüzyılın ise insan biçimini ortaya çıkardığı üzerinde durmaktadır. Kısacası, Akıl Çağı evrenin merkezine yönelik gözlemleriyle aşkın bir varlık olan Tanrı'nın sonsuzluğuna ulaşmış; 19. yüzyıl insanı ise hayat, emek, dil şeklindeki üç dış gücü kendinde içselleştirip bir sonluluk yaratmıştır (Akay, 2016, s. 108), (Foucault, 2015, s. 15). Nietzche'nin üst-insanı ise her ne kadar Nazizm tarafindan temellük edilse de aslının, Foucault'nun da 'insanın ölümü' kavramıyla ortak paydada insan biçimli dönemden makineleşme dönemine geçişle üçüncü bir çağın başladığını ifade etmede kullanıldığ 1 bilinmektedir.

Metnin devamındaki 'Yapısalcılık ya da en azından, az çok genel bu ad altında toplanan şey, zaman dolayımıyla bölüştürülebilen elemanlar arasında, bunları yan yana, karşılıkll, birbirini içerimleyecek biçimde, kısacası bir tür bileşim olarak ortaya çıkarabilen bir iliş̧kiler toplamı oluşturma çabasıdır; ve doğrusu, bunu derken, yapısalcılık zamanı inkâr etmemektedir; bu, zaman denen şeyi ve tarih denen şeyi ele almanin belli bir biçimidir' (Foucault, 2014, s. 292) sözleri de Foucault'nun tarihsel mutasyonunu desteklemektedir. Foucault, günümüz çağının aslında uzama yönelik bir yenilik getirmediği şeklinde yazısına devam ederken, Batı dünyasında zamanın uzamla kaçınılmaz ilişkisi neticesinde uzamın da kendine özgü bir tarihi olduğunu dile getirir. Ortaçağ'da hiyerarşik bir mekânsal tarih düzeninin 'kutsal ve dünyevi yerler', 'korunaklı ve açık, korunmasız yerler' ve 'kentsel ve kırsal yerler'le kurulduğundan bahseder. Bu hiyerarşinin gerçek insan yaşamı için gerekli görüldüğü gibi kozmolojik teoride de üst-göksel yerler, göksel yerler ve dünyevi yerler şeklinde birbirine zitlık oluşturacak hiyerarşilerin varlığından söz eder. Yani Foucault'ya göre, çok kabaca ortaçağ uzamı denebilecek şey -bir yere yerleştirilmenin (emplacement) uzamı-, tüm bu hiyerarşi, tüm bu karşıtlık, tüm bu kesişme yerleriyle kurulmuştur (Foucault, 2014, s. 292).

Foucault, bu yerleştirilme uzamının da Galileo'yla birlikte aşındığını, çünkü Galileo'nun Dünya'nın Güneş etrafında dönüşünü yeniden keşfetmiş olmasının aynı zamanda, sonsuz bir uzam kurarak; Ortaçağ yerinin bir anlamda bu uzamda eritildiğini söylemektedir. Yani, hiç bir şeyin hareketsiz kalmadığı Galileo'dan itibaren -on yedinci yüzyıldan itibaren- uzam/uzatma (extension), yerleştirilmenin (emplacement) yerine geçmiştir. Günümüzde ise, yerleştirilmenin yerini almış olan uzamın yerine noktalar ya da unsurlar arasındaki yakınlık ilişkileriyle tanımlananan mevki (site) ${ }^{10}$ geçmiştir (Foucault, 2014, s. 293). Foucault, günümüz diyerek 'mevki' şeklindeki değişime ilk olarak yaşadığı dönemde özellikle 1980 'lerde internet kullanımının yaygınlaşmasından etkilenmiş olacak ki-

\footnotetext{
${ }^{8}$ Bazı çevirilerde mekan dönemi şeklinde atfedilmiştir.

${ }^{9}$ Orijinal metinden çevrilmiş kaynaklarda, 'extension' kelimesi genişleme ve uzam anlamlarında kullanılmıştır.

${ }^{10}$ Orijinal metinden çevrilmiş kaynaklarda, 'site' kelimesi mekan, mevki ve uzam anlamlarında kullanılmıştır.
} 
Enformasyon Çağı'ndan (endüstri sonrası çağ) kesitler taşıyan örnekler vermiştir (bir makine hafizasında depolanan bilgiler, telefon hattındaki sesler). Sonrasında daha özel bir kavrayışla, yer ve mevkilendirme sorunsallaştırmasını demografik unsurlarla açıklamaya çalışarak bir nüfus planlamasının ötesinde mekanın insanlara mevkilendirme ilişkileri biçiminde sunulduğu ve böylelikle belirli bir durumda belirli bir amaca ulaşma gayesinde hangi yakınlı ilişkilerinin, insani unsurların hangi depolama, dolaşım, saptama ve sınıflandırmalarının benimsenmesi gerektiği üzerinde durmuştur (Foucault, 2014, s. 293).

Foucault'nun bu şekilde özne ve uzam anlayışında Akıl Çă̆ı'ndan 20. yüzyıla direkt bir sıçrama yaptığına parantez açmak gerekir ki, modern epistemin icatları olan mekanlara da değinmekte fayda vardır. Modernizmin inşa ettiği kapitalizmin temel dinamiklerinden biri de kontrol mekanizmalarının çeşitlenmesidir. Foucault'ya göre, kontrol mekanizmaları oluşturan iktidar ise, bunu dışsal olarak topluma dayatmaz. İktidar içseldir ve özne kendi iktidarını yaratır; iktidar sadece hükümet değildir ve her yerdedir. Hükümet yerine yönetim terimini kullanan Foucault, bu iktidar mekanizmaları için 'söylemsel pratikler' ve 'söylemsel olmayan pratikler' (Foucault, 2015, s. 15) şeklinde iki kavram geliştirmiştir. Örneğin, 'söylemsel pratik' olarak deliliği ele alırsak, 'söylemsel olmayan pratik' de akıl hastanesidir. Foucault, bu şekilde, sorunun/söylemin 'söylemsel olmayan pratikler'e eklemlenerek kurumsallaşan iktidar mekanizmalarının özne ve yönetimle birlikte dişli çark gibi sistematik bir şekilde çalışmasına 'hakikat oyunları' adını vermiştir. İnsanların bu hakikatlere inanması, yani iktidarın tanımladığı deneyim biçimlerini kendilerine özgü hakikatlar olarak algılaması ise, bu deneyimlerin öznesi olmayı kabullenmeleri anlamına gelmektedir. Böylelikle de, insanlar öznesi haline geldikleri deneyimlerin içerimlediği bilimsel, ahlaki, hukuki, siyasi normlara göre hareket etmekte ve kendilerini sinırlamaktadır (Foucault, 2015, s. 15).

Foucault, aslında yukarıda değindiğim dinamiğe benzer şekilde bu kez kutsallık sorunsalı bağlamında mekan irdelemeleri yapmaya devam etmektedir. Şöyle ki, yazısının devamında klasik epistemde teorik olarak kutsallıktan kurtulan mekanın, pratikte hala kurtulamadığına dikkat çekmiş; özel mekân/kamusal mekân, aile mekânı/toplumsal mekân, kültürel mekân/yararlı mekân, boş vakit mekânı/çalışma mekânı gibi karşıtlıklar oluşturarak dokunulmazlığını hala koruyan tüm bu mekanların hâlâ açıkça belli olmayan bir kutsallaştırmayla yönetildiğini dile getirmiştir. Bu kutsallaştırmayı, iç ve dış mekan diye kategorize ederek iç mekanları daha ruhsal deneyimlere ve yolculuklara açık oto-kontrol merkezli yerler; dış mekanları ise heteronomik bağlamda ilişkiler ağı içerisinde uyumlu ya da uyumsuz yerler olarak tanımlamıştır. Bu dış mekanlarla ilgili Foucault, "İçinde yaşadığımız, bizi kendi dışımıza çeken, özellikle yaşamımızın, zamanımızın ve tarihimizin erozyona uğradı̆̆ı mekân, bizi kemiren ve aşındıran bu mekân, heterojen bir mekândır. Başka deyişle, içine bireylerin ve şeylerin yerleştirilebileceği bir tür boşluk içinde yaşamıyoruz. Işıl lşıl farkl renklerle boyalı bir boşluğun içinde yaşamıyoruz, birbirine asla indirgenemez olan ve asla üst üste konamayan mevkiler tanımlayan bir ilişkiler bütünü içinde yaşıyoruz' (Foucault, 2014, s. 294). tanımlamasında bulunmuştur. Foucault, bu ilişkiler ağı içerinde konumlandırılabilecek yerler olarak pasajları, trenleri, sokakları bütünü betimleyen; kafeleri, sinemaları, plajları geçici/ara mevkiler; ve ev, yatak, odaları da kapalı/yarı açık dinlenme mevkileri şeklinde örnek göstermiştir. Burada, tüm bu mevkiler içerisinde Foucault'nun asıl ilgi alanında olan mevkilerde farkına varılması gereken husus ise, hem bunların diğer mevkilerle ilişkiler içinde olup hem de temsil ettikleri ilişkiler bütününü tersine çeviren veya yadsıyan mekanlar olmasıdır (Foucault, 2014, s. 295).

Foucault, bu mekanların ise ütopyalar ve heterotopyalar olarak iki ana türe ayrıldığını belirterek, bu terimleri tanımlamaya çalışır. Ona göre, gerçek yeri olmayan mevkiler olan ütopyalar, toplumun gerçek mekanıyla ya doğrudan ya da tersine bir ilişki içindedir. Dolayısıyla da, ya mükemmelleştirilmiş toplum ya da tersidir. Bununla birlikte, Foucault bu ütopyaların her halükarda gerçekdışı mekanlar olduğunu da tekrarlar. Burada, Foucault'nun olumsuz olarak ütopyanın anlam karşıtı olan distopyayı da ütopyalarla aynı şekilde betimlediği görülmektedir. Foucault gerçeklik anlayışına göre, yani gerçek bir yer oluşturması bağlamında ütopyanın karşısına heterotopyayı koymuştur. Heteropyayı ise, şu şekilde tanımlamıştır: 'Yine ve muhtemelen bütün kültürlerde, bütün uygarlıklarda gerçek yerler, fiili yerler vardır, bizzat toplumun kurumlaşmasında yer alan ve karşı-mevki türleri olan, fiilen gerçekleşmiş ütopya türleri olan yerler vardır -gerçek mevkiler, kültürün içinde bulunabilecek tüm diğer gerçek mevkiler bunların içinde hem temsil edilir hem de tartışllır ve tersine çevrilir-, bunlar fiili olarak bir 
yere yerleştirilebilir olsalar da bütün yerlerin dışında olan yer çeşitleridir. Bu yerler, yansıttıkları ve sözünü ettikleri tüm mevkilerden kesinlikle farklı olduklarından, bunlarl, ütopyalara karşıt olarak heterotopya diye adlandiriyorum' (Foucault, 2014, s. 295).

Foucault, hem ütopyalar hem de heterotopyalar için ortak bir deneyim alanı olarak aynayı önerir. Foucault'nun ayna önermesi, aynı zamanda çalışmanın giriş yazısında bahsedilen Lacan'ın 'Ayna Evresi' adını verdiği psikanalitik ve ontolojik çözümlemeyle de benzerlik taşır. Şöyle ki Lacan, ayna karşısında duran bir bebeğin ilk defa tutarlı bir kişisel kimlik deneyimi yaşayarak bir bilinç düzeyine ulaştığını ve bir benlik oluşturmaya başladığını söyler. Ancak bunun gerçekliğe yönelik bir sanrı da olduğunu, çünkü gerçek kimliğin sadece yansımadan ibaret olamayacağını da ilave eder. Buradaki asıl vurucu nokta ise; bebeğin uzamla kurduğu ilişkide yatmaktadır. Bebek, ayna evresi boyunca süren gelişiminde kendini, kendi dışındaki tüm varlık ve nesnelerle birlikte bir bütün halde hisseder; aynadaki görüntüsü ise, bu bütünlüğün parçalanmış halini sunmasından dolayı yaşadığı kimlik deneyimi, bebeğin bir o kadar da kendisine yabancılaşmasını meydana getirir. Böylece, bu bütünlük/parçalılık ilişkisine dayalı gerçeklik algısının başka bir varyasyonunu da Foucault'nun aynasında gözlemlemekteyiz.

Foucault, ayna önermesini şu şekilde açıklamaktadır: 'Ayna, sonuçta, bir ütopyadır; çünkü yeri olmayan yerdir. Aynada kendimi olmadiğım yerde görürüm, yüzeyin ardında sanal olarak açılan gerçekdışı bir mekânda görürüm, oradayımdır, olmadığım yerde, kendi görünürlüğümü bana veren, olmadığım yerde kendime bakmamı sağlayan bir tür gölge: Ayna ütopyası. Fakat, gerçekten var olduğu ölçüde ve benim bulunduğum yerde bir tür geri dönüş etkisine sahip olduğu ölçüde, ayna aynı zamanda bir heterotopyadır; kendimi orada gördüğümden, bulunduğum yerde olmadiğımı aynadan yola çıkarak keşfederim' (Foucault, 2014, s. 295). Bu anlatımıyla Foucault, aynanın bir tür illüzyon görevi üstlenmesiyle bir ütopya yarattı̆̆ını, ayna yüzeyinin ardında sanal bir mekan olduğunu ve insanın kendisini de orada, yani gerçekte olmadığı yerde görmesiyle de ütopik bir yer deneyimlediğini açıklamaktadır. Aynada kendini gözlemleyen kişinin aynadaki yansımasına bakarak gerçekte nerede olduğunu ve nerede durduğunu tayin etmesinin de bir tür heterotopya oluşturduğunu dile getirir. Metnin devamında heterotopyayı uzam ile kurduğu ilişkiyle daha net bir şekilde tanımlayarak, kişinin aynaya yansıyan bakışının gerçek kendi bakışıyla kesiştiği anda kişinin aynayla bir an için iletişimi kesip gerçek kendine yönelmesiyle gerçek yerde kendisini yeniden oluşturduğundan bahseder. Bu şekilde ayna, bakıldığı noktada onu çevreleyen tüm uzamla ilişki içinde kişinin işgal ettiği yerin hem gerçek, hem de o yerin yansımasının algılanması için oradaki bu sanal noktadan geçmesinin gerekliliğinden dolayı gerçekdışı olmasıyla heterotopik bir yer oluşturur. Böylece, Foucault'nun ayna ütopyası, Lacan'ın ilk kez kimlik deneyimi yaşayan bebeğin aynada ilk kez kendisiyle karşılaştığı o muğlak, o sanal ana denk gelirken; heterotopyası ise daha çok aynadaki konumunun uzamla girdiği ilişki içerisinde bebeğin kimliğine dair bir özbilinç kazanmasının yanı sıra kendisine yabancılaşmaya başlamasıyla ilgilidir.

\section{FOUCAULT HETOROTOPYALARININ ALTI İLKESI}

Foucault, soyut ayna örneğinden sonra heterotopyaları bir bilim olarak atfetmek yerine bir tür sistematik tanım şeklinde 'heterotopoloji' adıyla betimlenin daha doğru olacağı üzerinde durmuştur. Metnin sonrasında da heterotopyaları daha somut ve daha net örneklerle açıklayarak tümünü altı ilkede incelemiş ve değerlendirmiştir. Foucault'ya göre, heterotopyaların ilk kuralı, dünyadaki her kültürde varlıklarından söz edilebilir olmasıdır. Ancak, çok farklı çeşitli biçimlerdeki bu heterotopyaların ayrırt edici özelliği ise evrensel olmayışıdır. Hepsi kendine has kültür ve bölgelerde değişik biçimlerde insan grupları tarafından oluşturulmuş olsalar da, en azından genel anlamda iki büyük heterotopya türünden bahsedilebilir. Bunlardan ilki, ilkel diye tasnif edilen toplumlarda bulunan 'Kriz Heterotopyaları'dır (Foucault, 2014, s. 296). Bunlar, toplum içinde kriz durumlarında kalan bireylere (ergenler, âdet dönemindeki kadınlar, hamile kadınlar, yaşlılar, vs.) ayrılan ayrıcalıklı, kutsal ya da yasak yerlerdir. Kriz heterotopyaları günümüzde giderek kaybolmakta; ancak bazı bölgelerde (bu toplumun gelişmişlik düzeyi ile de alakalı olabiliyor) izlerine rastlanabilmektedir. Foucault, kriz heterotopyalarına geçmişten iki örnek gösterir: Bunlardan birincisi, erkek çocuklar için on dokuzuncu yüzyıldaki biçimiyle yatılı okul ya da askerlik hizmetidir (Foucault, 2014, s. 296). Çünkü o dönemde erkek çocuklar için cinsellik bağlamında erkek olma ya da sosyal anlamda yetişkin bir birey olma durumu, dışarıda aranan ve ancak dışarıda gerçekleşebilecek bir olgudur. Bu yüzden, erkekliğin aileden 'başka yerde' vuku bulması 
gerektiğinden dolayı yatılı okul ya da askerlik hizmeti böyle bir rol oynamıştır. Foucault, ikinci kriz heterotopyasını ise genç kızlar üzerinden örneklendirir ve yirminci yüzyılın ortalarına kadar "balayı seyahatleri" diye adlandırılan bir gelenek olduğundan bahseder (Foucault, 2014, s. 296). Yukarıdaki örnekte ataerkil düzenin erkeklere sağladığı özgürlüğün tam karşısına konumlandırılabilecek olan "balayı seyahatleri" genç kızların bekâretini kaybetmesinin "hiçbir yerde" gerçekleşemeyeceğinin sembolüdür. Bu yüzden, o dönem için coğrafi koordinatları olmayan heterotopyalar olarak tren ve balayı oteli, hiçbir yerin yeri olma durumunu tanımlamaktadır.

Kadın ve erkek üzerinden verilen bu kriz heterotopyalarının Foucault terminolojisine göre okunmasında fayda görülmektedir. Foucault, insan yerine özne demeyi tercih eder, çünkü insan ulaşabilecek bir varlık değil, hüküm içinde doğan bir varlıktır. Ancak, insan özne olarak da doğmaz ama özneleştirme sürecine girer. Foucault'nun daha önce 'insan biçimi' kavramından bahsedildiği üzere, kişi iç ve dış güçlerin birleşiminden yeni biçimler ortaya çıkarır ve insan kendi kendini özneleştirir. Böylelikle, Sartre'nin 'varoluş özden önce gelir' söylemiyle kişinin kendine bir öz yaratmasının özgürlüğü varoluşçu kılması, Foucault anlatısında yer edinemez. Çünkü Foucault'ya göre özgürlük iktidarın ürettiği bir kavramdır; özneler yaratılır ve özneler de bu yaratılanı kabul eder, içselleştirir. Dolayısıyla Foucault'nun analizine göre, kadın ve erkek diye de bir şey yoktur, bunlar yalnızca kültürel olarak kurgulanmıştır (Foucault, 2007). Böylelikle, tüm davranış biçimlerimiz sistemin içinde var olur; her yerde iktidar olduğu için de hakikati ve kendi özümüzü bulmak imkansızlaşır. Bilgide olduğu gibi cinsellikte de iktidarın kendini göstermesiyle cinsellik de söylemleştirilir. Foucault, önceden hazlar etkinliği olarak düşünülen cinselliğin, bazı dönemlerde sorunsallaştırılmas ${ }^{11}$ üzerine cinselliğin üç ciltlik tarihini yazar. Cinselliğin bir bask1 unsuru haline gelmesine Viktoryen dönemi örnek göstererek artık hazların da örgütlenip ve organize edilebilir oluşuna dikkat çeker (Foucault, 2007, s. 11-19).

Foucault, kriz heterotopyalarının yok oluşuyla birlikte onların yerine sapma heterotopyalarının geçtiğini belirterek yazısına devam eder ve bu tür heterotopyalar için şu tanımda bulunur: 'Davranışı, ortalamaya ya da istenen norma göre sapkın olan insanların içine yerleştirildiği heterotopya' (Foucault, 2014, s. 297). Foucault'nun bu betimlemesi de bize çok tanıdık gelir ve bu bizi onun biyoiktidar kavramına götürür. Foucault, bu terimi modernizm altındaki tüm kurumsallaşma gösteren yapılar için kullanır. Çünkü, ona göre 18. yüzyıl sonrasındaki (krallıklardan sonra) tüm modern iktidarlar, biyoiktidardır. Modern toplumun bir tür 'hoşgörü toplumu' olduğunu ve yine aynı hoşgörü çatısı altında kendi iktidar mekanizmalarını oluşturduğunu da ilave eder. Yukarıda da bahsedilen insanın kendini özneleştirmesinden önce bir de öznenin nesneleştirilmesi vardır ki, biyoiktidarlar bölücü pratiklerle ya özneyi kendi içinde böler ya da başkalarından bölüp ayırır. Bu şekilde, 'bölücü pratiklerle' deli ile akıllıyı, hasta ile sağlıklıyı, suçlular ile 'iyi çocuklar'ı bölüp birbirinden ayıran sınıflandırma düzeni, öznenin nesneleştirilme sürecini başlatır (Foucault, 2015, s. 15-16). Modern toplumlarda hastane, hapishane gibi kavramların ortaya çıkması da, eski usul ölümcül cezai sistemler yerine hasta olanın tedavi edilerek, suçlu olanın ıslah edilerek kapitalizmin ihtiyacı olan iş gücünün bedenlerden karşılama gereksinimden kaynaklanmaktadır. Bu yüzden de, Foucault feodal dönemde suçluların ölümle cezalandırıldığı sisteme nispeten modern kapitalizmin zaptetme yöntemiyle bedenleri nesneleştirmesini, modern toplumların 'höşörülülükle' özneyi nesneleştirmesine dayandırmıştır. Dolayısıyla 'sapma' ile 'bölücü pratikler' terimleri arasında bir anlam bağı da kurulabilir olmasıyla sapma heterotopyalarının biyoiktidar mekanizmalarıyla ilişkili bir şekilde dinlenme evleri, psikiyatri klinikleri ve hapishaneler olduğunu söyleyebiliriz. Foucault, heterotopya betimlemelerinin ilk ilkesinin bitimine doğru ayrıca bir not düşer: 'Boş zamanın bir kural olduğu toplumumuzda aylakllğın bir tür sapma ve yaşlılığın da bir kriz fakat aynı zamanda bir sapma olmasından dolayı huzurevleri, kuşkusuz kriz heterotopyasinin ve sapma heterotopyasinin bir anlamda sinırindadir' (Foucault, 2014, s. 297).

Heterotopyaların ikinci ilkesinde ise, Batı kültüründe mezarlıkların zaman içinde nasıl işlev değişikliğine uğradığı anlatılmaktadır. Bir toplumun, tüm tarihi boyunca adeta kültleşmiş bir halde var olmaya devam eden bir heterotopya, içinde bulunduğu kültüre ve sosyal çevreye göre, anlam bağlamının çok ötesinde faaliyet gösterebilir. Metinde, 18. yüzyılda kentlerin merkezinde, kilise

\footnotetext{
${ }^{11}$ Krizin de bir tür sorunsallaştırma anlamı taşıdığı düşünülebilir. Çünkü bir kriz durumu sorunların baş göstermesi sonucunda ortaya çıkarken, krizin bitmesi için de sorunların tespit edilip, sorunsallaştırılması gerekir.
} 
çevresine konumlandırılan mezarlıkların, 19. yüzyıldan itibaren şehir dışlarına doğru kaymaya başlaması örnek gösterilmiştir (Foucault, 2014, s. 298). Yani, mezarlıklar alışıldık coğrafi belirteçlerini başka toposlarda farklılaştırarak yer almaya başlamıştır. Foucault, 'Of Other Spaces' konferans metninin girişinde Ortaçağ' $1 n$ hiyerarşik bir mekânsal tarih düzenine sahip olduğuna dikkat çekmiştir. Aslında mezarlıklardaki bu konum değișimin de Foucault'nun epistem adını verdiği bilgi edinme metodundaki değişiklikten kaynaklandığı söylenebilir. Şöyle ki, Ortaçağ insanı 'memonto mori' mottosuyla kutsal bir yer olan kilisenin göksel olanla tek bağlantı noktası olduğuna ve yeniden dirileceği zaman da ölü bedenini kiliseye yakın tutarak öteki yaşama geçişteki yolu da kısaltacağına (kolaylaştıracağına) ve daha da kutsanacağına inanmıştır. Yani, ölüm meselesi de mezarın kilisenin içindeki konumu da kendi içinde bir hiyerarşi barındırmaktadır. Kilisenin içindeki mozole veya anıt tipi mezarlardan, isimli veya isimsiz pek çok mezarın kilise çevresinde konumlandırılması, tanrıya ulaşma erekselliğinin hiyerarşisi anlamı taşımaktadır. Ortaçağ' dan klasik epistemi de içine alan çok uzun bir süre, bu ölü kültü pek bir değişikliğe uğramamıştır. Çünkü tanrının gözü ${ }^{12}$ olan kiliselere yakın olmak, tek gerçek iktidar olan Tanrı'ya yakın olmak demektir. Ancak, iktidar gözlerinin 19. yüzyıldan itibaren çeşitlik göstermesi, örneğin mezarlığın bile burjuvazi tarafından sahiplenilmesiyle birlikte ölüm uğursuz, hastalıklı bir durum olarak görülmüştür. Böylelikle, ölülerin yaşayanlara hastalık getireceği korkusu ve mezarlıklardan salgın yoluyla yayılan hastalık temasıyla mezarlıklar, banliyölere doğru taşınmaya başlamış ve bu şekilde ölüm uzaklaştırılmıştır. 19. yüzyıl boyunca ölüm ve ölüler dışlanmış; her ailenin kendi karanlık ikametine sahip olduğu 'ölüler şehri' şehrin uzaklarında 'öteki şehir'i meydana getirmiştir (Foucault, 2014, s. 298).

Üçüncü ilke ise tek bir gerçek yerde birbiriyle çelişkili ya da uyumsuz birçok mekan ve mevkiyi bir araya getirebilme potansiyeli olan heterotopyalardır. Bunlara ilk örnek olarak tiyatro ve sinemalar verilmiştir (Foucault, 2014, s. 298). Bilindiği üzere tiyatrolar belirli sahnelerden oluşur ve her bir sahne kendine özgü bir mekanla kurgulanır. Bu şekilde, birbirinden farklı mekan kurgularının sahne denilen tek gerçek bir yerde toplanmasıyla oyun oluşur. Tiyatronun tüm mekanlarındaki üç boyutluluğunun aynı kalıp, sadece sahnenin iki boyuta indirgenmesiyle ekrana dönüşmesi ise sinemayı oluşturur. Yani, sinemada iki boyutlu bir ekrana üç boyutlu bir mekan yansır. Ancak, bunlar daha çok Foucault'nun mekana dair geliştirdiği teknik ve işlevsel görsel anlatılardır. Günümüzde kentsel heterotopyalardan tutun, alışveriş merkezlerine ve hatta turizm destinasyonlarına kadar birçok çelişkili mekanın bir arada tek bir yerde bulunduğu söylenebilir. Ayrıca, sinema ve tiyatronun yarattı̆̆ı mekânsal yanılsamacıllı̆ın güncel en uç örneği olan VR gözlükleri de, gerçekliğin algılamıyla ilgili tezatlıklar içermektedir. Bu yüzden, Foucault’nun bu heterotopya örneğinin ucu açık bırakılmasından dolayı, farklı ilişkiler ağı içerisinde incelenebileceği görülmektedir.

Foucault'ya göre en eski çelişik mevkiler örneği ise bahçedir. Binlerce yıllık geçmişi olan bahçeler, Doğu'da çok mistik ve ezoterik katmansal anlamlar içerir. Örneğin, geleneksel Acem bahçesi, dünyanın dört diyarını dört köşesinde bir araya getiren kutsal bir mekandır. Bu bahçenin en kutsal bölümünü ise merkezindeki havuz ve su fiskiyesi oluşturur ve bahçenin havuzlu merkezi dünyanın merkeziyle aynı yerdedir. Böylece, tüm bitki örtüsü bu mekanda, bu tür mikrokozmosta bir araya gelir (Foucault, 2014, s. 298). Foucault, burada daha sembolik bir anlatım diline başvurarak, dünyaya karşılık gelen bir metafor olarak bahçeyi evrenselleştirici bir heterotopya olarak değerlendirmiştir. Dolayısıyla, bahçeyi sadece uyumsuz mekanların toplandığı heterotopik bir yer tasviri şeklinde değil de, hakikat problemi/yanılsama yaratan heterotopyalar olarak da tanımlamak gerekecektir. Ayrica, Foucault'nun dünyanın merkeziyle aynı yere denk düşen bahçenin merkezine yaptığı gönderme, kozmolojik bir veriden öte hakikat ve köken sorunsalı teşkil etmektedir. Çünkü daha öncede değinildiği gibi evrenbilimsel tarih anlatısında da, bireyin salt gerçekliği, evrenin bütünsel düzenine müdahil değil miydi? Bu yüzden, evrenbilimsel düzenin küçük bir şemasına dönüşmüş olan bu bahçe, bir bakıma çelişki ve tezatlıkları homojenleştiren bir yapıya işaret etmektedir. Bahçenin merkezindeki havuzun imlediği yaşamın kaynağı olan su da, aşkın bir mertebede evrenin ve bilginin kökenini temsil eder.

\footnotetext{
12 İngiliz filozof Jeremy Bentham'ın ideal hapishane olarak tasarladığı Panoptikon, Foucault’ya göre disiplinin mahkumlar tarafından içselleştirilmesidir. Ortaçağ epistemindeki 'Tanrının gözü' de aynı Panoptikon'daki mahkumların ne zaman gözlendiklerini bilmedikleri (gözleyen gözlenenler tarafından görülemez) için sanki her zaman gözleniyormuş gibi hareket etmelerine neden olan işlevselliktedir. Panoptikon ilkesinin hapishane dişında başka kurumlarda kullanılmasıyla da Tanrı'nın gözünün bir bakıma İktidar gözüne dönüştüğünü söyleyebiliriz.
} 
Böylelikle, bahçe tüm insani değerleri tek bir çatı altında toplayan; yaşam ve bilgi kaynağını tek bir merkezde sunarak havuzdan tüm çevreye yayılmak suretiyle evrenbilimsel bir düzen inşa eden mutlu ve evrenselleştirici bir heterotopyadır.

Ancak, Foucault evrenbilimsel düzene bu kadar optimist bakmayan Nietzsche'nin, bilgi ve köken sorununa çok farklı yaklaştı̆̆ını dile getirir ve Nietzsche'nin zamanın belirli bir noktasında ve evrenin belirli bir yerinde zeki hayvanların bilgiyi icat ettiğini ileri sürdüğünü ekler (Foucault, 2015, s. 169). Nietzsche icat der; çünkü dinin icat edilip, kökeninin olmaması gibi bilginin de kökeni yoktur. Bu yüzden, metinlerinde polemik bir anlam ve ifade kaygısı taşıyarak kullandığı 'icat' kelimesi (Alm. Erfindung), Nietzsche'ye göre 'köken'in (Alm. (Alm. Ursprung) karşıtıdır. Bununla birlikte, bilginin bilinecek şeylerle ve hatta bilinecek dünyayla da yakınlık ilişkisi yoktur. Bu yüzden, Nietzcshe 'Dünyanın bütününün karakteri, zorunluluk yokluğundan dolayı değil; düzen, eklemlenme, biçim, güzellik, bilgelik yokluğundan dolayı ezelden beri kaosun karakteridir' (Foucault, 2015, s. 172) açıklamasında bulunur. Çünkü dünya insanı taklit etmeye çalışmaz ve hiçbir yasa tanımaz. Bilgi ile bilinen şeyler arasındaki ilişki, iktidar ve şiddet ilişkisine dayalıdır. Böylece, bilgi sisteminin merkezinde artık, Tanrı'nın varlığı da zorunlu değildir. Bilginin mücadele etmek zorunda olduğu dünya düzensiz, bağlantısız, biçimsiz, güzelliksiz, bilgelikten yoksun, uyumsuz bir dünyadır (Foucault, 2015, s. 172).

Heterotopyaların dördüncü ilkesi ise daha çok zamanla ilişkili olup, mekan içerisinde farklı boyutta birer zaman edinimine odaklanmalarıdır. Foucault, geleneksel zaman tabiriyle kastettiği tarihsel zaman anlayışından kopuk bir şekilde zaman dilimlerindeki birikmeler, bölünmeler ve farklılıklara 'heterokroni' adını vermiştir (Foucault, 2014, s. 299). Bu bakımdan mezarlıkları tekrar ele alan Foucault, bir bireyin yaşamının yok olması, silinmesi açısından hem kaybolmayı hem de sonsuzluğu simgeledikleri için mezarlıkları oldukça hetorokronik yerler olarak görür. Foucault, genel bir tanımdan sonra heterokronileri üçe ayırır. Bunlardan birincisi, sonsuz zaman biriktiren müze ve kütüphanelerdir. Zamanın yı ğılmasına olanak veren bu mekanlardan müzelerde, daha çok tarihsel bir birikim söz konusuyken, kütüphanelerde de bilgi birikimi mevcuttur. Ancak, Foucault müzeleri bir tür kültürel bellek işlevi görmelerinden dolayı, günümüz müze ve hatta sanat galerilerinden ayırır. Çünkü retrospektif ve seçki niteliğindeki eserleri bünyesinde barındıran müzeler, tarihe ve zamana dair ancak küçük bir kesit sunabilir. Oysaki modernizmi inşa eden mekanlar olarak nitelendirilen müzeler kapsamlı bir tarihsel birikime sahiptir. Ancak, Berlin Altes, British Museum gibi birçok Avrupa müzesi de siyasi eleştirilerin hedef noktasında kalmıştır. Çünkü kendi kültürü dışında çok farklı kültürlere ait sanat eserlerini yığmacı bir anlayışla tahakküm altına almaları dolayısıyla kolonyal politikalara hizmet ettikleri gibi çıkarımlar yapılmıştır. Kimi çevrelerden ise sadece evrensellik adına atılan büyük bir adım olarak görülerek olumlu tepkiler almıştır. Zaten Foucault da bu farkındalıkla şu sözleri sarf etmiştir: 'On yedinci yüzyıl sonuna kadar müzeler ve kütüphaneler kişisel bir tercihin ifadesiydi. Buna karşılık, her şeyi biriktirme fikri, bir tür genel arşiv oluşturma fikri, bütün zamanlarl, bütün dönemleri, bütün biçimleri, bütün zevkleri bir yere kapama istenci, zamanın dışında yer alacak ve zamanın zarar veremeyeceği bir yer oluşturma fikri, kımıldamayacak bir yerde zamanın bir tür kalıcı ve sonsuz birikimini örgütleme projesi; tüm bunlar bizim modernliğimize aittir. Müze ve kütüphane, on dokuzuncu yüzyll Batı kültürüne özgü heterotopyalardır' (Foucault, 2014, s. 299).

İkinci tip ise, birincinin tam tersine geçici zamana bağlı heterokronilerdir. Bunlar, geçici bir şekilde kurulan panayırlar, sirkler, fuarlar ve festivaller gibi genellikle eğlence amaçlı düzenlenen mekanlardır (Foucault, 2014, s. 299). Kronik heterotopyalar oldukları için boş alanları ve dolayısıyla şehir kıyılarını mesken edinirler. Bazı fuarlar ise ayda bir veya yılda bir gibi belirli periyotlarda aynı mekanlarda tekrarlanır ve işlevlerini yerine getirip sürelerini doldurdukları anda da arkalarında Foucault'nun tasviriyle olağanüstü bir boşluk bırakırlar. Son olarak üçüncü tip heterokroniler ise, ilk ikisinin sentezi olan tatil köyleridir (Foucault, 2014, s. 300). Çünkü bunlar, hem sonsuz zaman biriktiren hem de eğlence odaklı mekanlardır. Örneğin, Polinezya köyleri sakinlerine buradaki ilkel yaşamı deneyimleyebilme fursatı sunduğu için adeta zamanı ortadan kaldırmış gibi olurlar. Böylelikle, Djerba'daki saz kulübeler, kütüphanelerin ve müzelerin işlevselliğine benzerlik göstererek zamansızlık yaratırlar. Aslında, buradaki zamansızlık aynı zamanda kavuşulan zaman olduğu için kütüphane ve müzelere koşutturlar. Çünkü ortadan kalkan zaman bir tür tüm zamana kavuşmak gibidir; sanki tüm insanlık tarihine dolaysız bir tür büyük bilgi gibi kavuşmuşuzdur (Foucault, 2014, s. 300). Kısacası, 
Foucault ilkel yaşamı deneyimlemeyi insanlığın en başına götüreceği düşüncesiyle o zamanlar için daha bir tarih yazılmamış olduğuna dikkat çeker ve tarihsizlik de zaten zamansızlık, zamanı ortadan kaldırmak demektir. Ayrıca, şimdiden geçmişe, geriye doğru yapılan bu yolculuk da, aradaki tüm zaman dilimleriyle birlikte geçmişten günümüze kadar tüm insanlık tarihine hakim olduğumuz anlamına gelmektedir. Dolayısıyla, tecrübe ederek, yaşayarak edindiğimiz bir insanlık tarihi bilgisine sahip olmamız bizi tüm zamanlara kavuşturmuştur.

Heterotopyaların beşinci ilkesi ise, ulaşılabilirlik ya da yalıtılmışlık açısından mekanların kendi içinde bir açılma ve kapanma sisteminin olmasıdır. Genellikle, hiçbir heterotopyaya da bir kamusal alandaki gibi rahatlıkla giriş, çıkış yapılmaz. Dolayısıyla bu tip heterotopyalar dörde ayrılır. Bunlardan birincisi, tamamen kapalı olan heterotopyalardır. Örneğin, kışla ve hapishaneler girişi zorunlu, ancak çıkışı izne bağlı olan mekanlardır. Bunlar, sapma heterotopyalarında da bahsedildiği gibi kontrol mekanizmalarıdır. İkincisi ise, sınırlı giriş-çıkış yapılabilen heterotopyalardır. Yani, giriş yapabilmek için belirli ritüel ve buyruklara uymak zorunda olduğumuz mekanlardır. Foucault, bu heterotopyalara arınma faaliyetleri ile ilintili bir şekilde Müslüman hamamları ile İskandinav saunalarını örnek gösterir. Ancak, Müslüman hamamlarındaki arınmanın hem sağlık hem de din ile ilgili; İskandinav saunalarındaki arınmanın ise sadece sağlıkla ilgili olduğunu da ekler. Bizim toplumuzda camilerdeki gibi daha çok dini değerlerin baskınlığından kaynaklı mekânsal kurallar konulmuşsa da, bu kısıtlamalar kültürlere göre değişiklik gösterebilir. Üçüncü tip heterotopya ise girişi serbest olmasına rağmen çeşitli dışlanmaların rastlanıldığı mekanlardır. Kişi istediği gibi girdiğini zanneder, ama aslında bu bir yanılsamadır. Bunlara örnek olarak, Brezilya'nın büyük çiftliklerinde ve Güney Amerika'nın bazı yerlerinde bulunan konuk odaları gösterilebilir. Oralara yolu düşen her yolcu bir gece dinlenmek ve uyumak için bu odalarda konaklayabilir, ancak ailenin bulunduğu odalara giremez. Evin konuk odalarının mimarisi de zaten tecrit edilmek üzere tasarlanmıştır. Kişi bu yüzden, kabul edilmiş olsa da aynı zamanda dışlanmıştır. Açılma-kapanma sistemli son heterotopya da aslında bir öncekinin farklı bir varyasyonudur. Üçüncü tipin artık Batı kültüründe pek var olmadığını belirten Foucault, son gruba özellikle yol kenarlarında bulunan Amerikan motellerini dahil eder. Şöyle ki, arabayla gelinip yanında metresle giriş yapılan bu mekanlar, gayrimeşru cinsellik amaçlı kullanılmakta ve bu oldukça korunaklı ve gizli bir şekilde gerçekleşmektedir. Dolayısıyla, üçüncü heterotopyadaki dışlanmanın burada gizliliğe dönüştüğünü söyleyebiliriz.

Son olarak üçüncü tip heterotopyalara dahil olabileceği düşünülen bir örnekten bahsedebiliriz. Foucault'nun açılma-kapanma sistemli heterotopyalarında dini, askeri, kültürel ve cinsellik bağlamındaki mekanlar ele alınmıştır. Burada ortaya konulacak önerme ise kendi içinde bir hiyerarşi barındıran kamu yapılarıdır. Özellikle, köklü üniversiteler ve içindeki birimleşme buna örnek gösterilebilir. Örneğin, bir fakülteyi onu oluşturan birimleriyle birlikte düşünürsek, dekanlık, anabilim başkanlığı, bölüm başkanlığı gibi sıralanabilir. Ancak, burada dikkat çekmek istenilen nokta, makam odalarıdır. Çünkü, üniversite birimi dahilindeki odalara serbestçe girilebilmesine rağmen, üçüncü heterotopya tipindeki dışlanma burada da hissedilir. Örneğin, üniversitenin en üst mevkisinin rektöre ait olduğu bilinir. Hukuki ve idari çerçevede bir rektörün müsait olma durumuna göre odasına girilmesinde bir mahzur da yoktur. Öğrencisinden profesörüne kadar herkes, rektörün odasına girip onunla görüsşebilir. Ancak, bu bizim toplumumuzda uygulanmadığ gibi pek de kabul görmez. Üniversitelerdeki hiyerarşik görüşme biçimleri en üstten en alta tüm birimlerde kendini gösterir. Foucault ise birimleşme dediğimiz bu durumu, 'blok' mefhumu içinde değerlendirir. Ona göre, 'kapasitelerin ayarlanmasının, iletişim şebekeleri ve iktidar ilişkilerinin düzenli ve uyumlu sistemler oluşturduğu 'bloklar' vardır. Bir eğitim kurumunun mekânsal düzeni, kendi içsel yaşamını yönlendiren ayrıntıl düzenlemeleri, orada düzenlenen değişik etkinlikler, tanımlanmış işlevleri, yerleri ve yüzleriyle yaşamını o kurumda geçiren ya da orada birbirleriyle karşılaşan çeşitli bireyler; bütün bunlar, bir kapasite-iletişim-iktidar bloku meydana getirir' (Foucault, 2014, s. 71).

Başka bir örnek olarak adliye binalarındaki mahkeme salonları incelenebilir. Mahkeme salonları ise sınırlı giriş-çıkış yapılabilen ikinci tür heterotopyalar grubuna girer. Yine bizim toplumuza has bir özellik olarak mahkeme salonlarında duruşma öncesinde, duruşma esnasında ve hatta sonrasında uygulanması gereken davranış biçimleri vardır. Mahkeme salonlarına girilmesinden hakimle konuşma tarzına ve sanıkla birlikte salondaki herkesin giyim ve kuşamına kadar her şeyin belirli bir kuralı, sınırı ve eylem biçimi vardır. $\mathrm{Bu}$ durumun adalete ve hukuka duyulan saygıdan kaynaklandığı 
düşünüldüğünde özellikle bizim toplumumuzda bu kadar keskin ve ciddi ayrımların bulunduğu söylenebilir.

Heterotopyaların sonuncu ilkesi, birbirine bağladığı diğer tüm mekanlarla ilişki içerisinde olmasıdır. Yani, bir heterotopyanın dışında kalan mekanlar açısından da bir işlevi vardır. Bu işlev, iki ekstrem kutup arasında ortaya çıkar (Foucault, 2014, s. 301). Böylelikle, bu heterotopyaların birinci rolü, her gerçek mekanı insan hayatının bölümlenmiş olduğu tüm alanları içinde daha da aldatıcı olduğu gibi ortaya koyan bir yanılsama alanı yaratmaktır. Örneğin, genelevler böyle bir özellik taşır; çünkü sadece cinsel arzuların gerçekleştirildiği yerler olmalarının dışında gerçek hayattaki davranışların dışında hareket edildiği için insanları kendi hayatlarından farklılaştırmaları dolayısıyla bir yanılmasa yaşatırlar. $\mathrm{Bu}$ heterotopyaların tam tersi özellikteki ikinci rolü ise, bizimki gibi düzensiz, kötü inşa edilmiş, karmakarışık düzenlenmiş mekanlara karşın, bir o kadar mükemmel, titiz ve düzenli yerleştirilmiş diğer mekan olan, bir başka gerçek mekan yaratmaktır. Foucault'ya göre bu tip mekanlar, yanılsamanın değil; ‘ödüllendirmenin heterotopyası' olarak adlandırılır ve kısmen bazı koloniler bu tarzda işlev görür (Foucault, 2014, s. 301).

Foucault, bu mükemmelleştirilmiş topluluklar olarak Püriten ve Cizvit kolonilerini örnek gösterir. On yedinci yüzyılda, birinci sömürgecilik dalgası sırasında İngilizlerin Amerika'da kurduğu Püriten topluluklarını ve yine, Güney Amerika'da kurulmuş olan Cizvit kolonilerini 'insan mükemmelliğinin fiilen gerçekleştiği, son derece kurallı, harikulade koloniler' (Foucault, 2014, s. 301) şeklinde nitelemektedir. Bu durumda, Foucault'nun bu koloniler için kullandığı 'ödüllendirmenin heterotopyası' adlandırmasının muğlaklığını gidermek, en azından yorumlamak gerekecektir. İlk başta, Foucault'nun bunun tüm koloniler için geçerli olmadığının farkındalığıyla söylediği cümle arasında geçirdiği 'kısmen bazı koloniler' sözlerinden anlaşılmaktadır. Ancak, birçok koloninin tahakküm altında kalması dolayısıyla özellikle ekonomik ve kültürel sıkıntılar yaşadığı bilinen bir gerçekken, sömürgeleştirme politikalarına amiyane tabirle bir mükafatmış gibi yaklaşılması taraflı bir görüşün göstergesidir.

Foucault, sonrasında Cizvitlerin yaşamına dair kesitler sunarak yazısına devam ederken, onların dini inanışları çerçevesinde nasıl planlı bir yerleşim yapılandırdıklarına (haç şeklinde yerleşim düzeni) ve kurallara sıkı sıkı bağlı sosyal bir yaşam sürdüklerine değinmiştir. Foucault'nun her iki koloni örneği de, dini merkezli toplumların azınlıkken, zamanla büyük politik ve ekonomik güçler haline gelmeleriyle mensup oldukları devletten farklılaşarak çok başka bir 'öteki mekan' yarattıklarını açıklamaktadır. Bu farklılaşma bizi aynı zamanda Platon'un 'ideal devlet'ine götürür. Daha öncede değinildiği üzere, Platon bireyin toplumsuz kendi başına bir fayda sağlamadığı ve bir anlam ifade etmediği görüşündedir. Bu yüzden, devleti doğal bir düzen olarak canlı bir organizmaya benzetmiştir. Dolayısıyla, devletin her organı ancak bütün bir yapı (beden) içinde yaşayabilmektedir. Böylelikle, organın beden dışında yaşayamaması durumu 'bedensiz organ' mefhumuna karşılık gelmektedir. Ancak, Cizvit kolonilerinde bu durum tam tersi şeklinde yaşanmıştır. Devletsiz, küçük bir azınlık olarak kendi inançları doğrultusunda yaşayabilmeyi başarmışlardır. Bu da demek oluyor ki, onlar 'organsız bedenler'dir. Ancak, Artaud'un keşfettiği bir söylem olarak 'organsız beden' aslında organizmalara karşıdır. Yoksa zaten organlar dışarıda yaşayamaz ama beden de asla bir organizma değildir: 'Beden bedendir, yalnızdır ve organlara ihtiyacı yoktur' (Zourabichvili, 2011, s. 133). Organsız beden (OsB) fikrini ele alarak birçok farklı kavram geliştiren Deleuze de bir ayrıma dikkat çeker: OsB, her organın kendi yerinde olduğu, her organa kimliğini belirleyen bir rolün tayin edildiği organizmaya karşıdır (Zourabichvili, 2011, s. 135). Yani, organların organizasyonuna, organların organize işleyiş̧ine karşı olunmasından dolayı organizmalar bedenin düşmanıdır. Sonuç olarak, örnekte verilen kolonilerin köklerinden koparılarak mevcut toplumsal düzenin dişında kalmaları 'organsız beden' fikrine uygun düşerken, aynı zamanda onları yurtsuzlaştırmaktadır. Ancak, kolonilerin öncekisinden farklı bir yerde ve farklı bir sistemle yeni bir oluşla toplumsal yapının tekrar ögeleri haline gelmeleri de onları tekrar yeryurt sahibi yapmaktadır.

\section{SONUÇ}

Foucault'nun kendi deyimiyle arkeolojik bir kazıya benzettiği 'kökenbilimsel' metodolojiyle geliştirdiği 'sorunsallaştırma' tekniği cinselliğin, deliliğin ve cezanın tarihini yazmasındaki mihenk taşıdır. Çünkü Foucault, bu teknikle bazı dönemler için sorun edilmiş olguları gün yüzüne çıkarmakla kalmaz; o dönemin tüm toplumsal ve kültürel değerlerini, yönetim biçimlerini kapsayan gerçek bir 
insanlık tarihi külliyatı ortaya koyar. Farklı dinamik ve parametrelerle oluşturduğu iktidar mefhumu da, toplumun özneleri olan bizlere yaşamın gerçekte ne olduğuna dair yeni bir bakış açısı kazandırır. Örneğin, 18. yüzyıl sonrası tüm modern iktidarları tanımlamak için kullandığı biyoiktidarların 'bölücü pratiklerle' deli ile akıllıyı, hasta ile sağlıklıyı, suçlular ile 'iyi çocuklar'ı bölüp birbirinden ayıran sinıflandırma düzeniyle öznenin nesneleștirildiğini öne sürer. Topos'a sosyal ve kültürel farklı boyutlar katarak özne ve iktidar kuramlarıyla ilintili geliştirdiği 'Heterotopya'ları ise hayatımızın her alanını işgal eden ama bizim farkında bile olmadığımız mekanlar, yerler, uzamlardır. Foucault'nun sistematikleştirdiği iktidar mekanizmalarının görünür ve bilinir yasak ve kısıtlamalarından farklı olarak bu öteki mekanların kültürel ve sosyolojik kuralları özneler tarafından gönüllükle kabul edilir ve uygulanır. Foucault'nun bilgi/iktidar kavramının ilişkiler ağ iç̧erinde deneyim biçimleriyle ilintili olan öznenin nesneleştirilmesi ve kişinin kendini özneleştirmesi bu kabullenişi açılayan olgulardır. Çünkü Foucault'nun tarihi mekan yaratır; şöyle ki her yeni bir sorunsallaştırma, iktidar mekanizmalarına yeni bir yer, yeni bir alan açar. Örneğin, cezanın tarihi yazılırken bir sorun olarak suç söylemleştirildiğinde, suçun kendisi özel bir deneyim haline dönüşecektir. Bu deneyimin öznesi olmayı kabul eden kişi de, davranışlarını deneyimlerin içerimlediği normlara göre sınırlandıracak, disiplini içselleştirerek kişi kendisini özneye dönüştürecektir. Böylelikle, sorunsallaştırmanın gerektirdiği söylemsel pratik, suç; araştırma alanı için gereken ortamı sağlayan kurum da hapishane olacaktır. Yani, söylemsel olmayan pratiklerden hapishane, suçun sorunsallaştırılması sayesinde ortaya çıkan bir kurum olmuştur.

Heterotopyalar da, bazen aynı şekilde deneyim biçimleri sunabilmektedir. Örneğin, sınırlı giriş-çıkış yapılabilen heterotopyalardan olan hamama giriş yapabilmek için belirli ritüel ve buyruklara uymak zorunludur. Dolayısıyla, kültürel kodların bize sunduğu gönüllü kabullenişle de bir bakıma kişi kendisini özneye dönüştürür. Ayrıca heterotopyalar öznelerin nesneleştirilmesiyle alakalı tüm politik, dini, kültürel söylemlerin farklılaşmasından kaynaklanan dönemsel koşullara göre anlam kaymalarına uğrayabilirler. Ancak, iktidarın gücü için elzem olan kontrol mekanizmalarının aksine inşası zorunlu olmayan daha plansız, doğal ve hatta bazen kişisel olan heterotopyalar da vardır. Bunun yanı sıra, heterotopyaların öznelerle ve diğer mekanlarla kurdukları ilişkiler neticesinde türlerinden bazıları yok olabilirken yenilerinin eklenmesiyle çeşitleri de artabilir. Tam tersi şekilde, insani eylemlerden özerk, mistik ve ezoterik anlamlarla yüklü heterotopyalar da vardır; Doğu'ya özgü bahçeler ve Budist tapınakları bunların en güzel örneğidir. Her zaman belirli coğrafi işaretler ya da mekansal düzenlemeler gerektirmeyen genellikle gemiler ve halılar gibi heterotopyalar ise sembolik ve soyut anlamlar içerirler. Sonuç olarak, Foucault'nun 'gerçekleşen ütopyalar' şeklinde tanımladığı heterotopyalar, toplumun kurumsallaşmasında yer alan ötekiliğin gerçek mekanları/uzamlarıdır. İktidar mekanizmalarına nazaran daha olumlu çağrışımlarda bulunan birbirini tersleyen ya da ilişki kuran, sıra dışı, akışkan heterotopyalar ne kamusal alanlar gibi kolay ulaşılabilirliği olan yerlerdir ne de sadece iktidar tahakkümünün yarattığı gibi mekanlardır, onlar öteki, başka uzamlardır; ilişkiler ağı içerisinde özne ve yaşamlarla kaçınılmaz iletişimi ve sonsuz etkileşimi olan rejeneratif dinamiklerdir.

Rejeneratif dinamikler, biyolojik bir bağlamda Foucault'nun 'insan biçimi' ile ilişki kurar. Foucault, insan biçimini, onu meydana getiren içsel ve dişsal güçlerinin birleşiminin yeni bir form alması şeklinde tanımlar. Foucault, Klasik Çağ insanının aşkınlık ve içkinlik mefhumlarıyla ilintili bir şekilde içsel ve dışsal iki bileşiminin Tanrı fikrini; 19. yüzyıl insanının da hayat, emek, dil şeklindeki üç dış gücü kendinde içselleştirmesiyle insan biçimini ortaya çıkardığını söyler. Böylece rejeneratif dinamikler, insan biçiminin tarihsel koşullara bağlı bir şekilde başka yeni birleşimlerden meydana gelmesine neden olan güçlerin de sürekli olarak değişmesi ya da yenilenmesi olarak açıklanabilir. Foucault, dış güçleri genellikle, toplumsal ve tarihsel oluşumların etkisi altında şekillenen iktidar mekanizmaları olarak açıklar. Şöyle ki, Foucault Klasik Çağ ve 19. yüzyıl insan biçimlerinden örnek verirken, bir bakıma insanı biyolojik bir varlık olmaktan çıkararak ona kimlik kazandırmaktadır. Dolayısıyla, Foucault'nun sorunsallaştırma tekniği ile Lacan'ın özneleşme süreci benzerlikler gösterir. Foucault'ya göre, herhangi bir olay veya olgu söylemleştirildiğinde, o sorun deneyim haline dönüşecektir. Kişi de davranışlarını deneyimin izin verdiği eylemsel ve düşünsel çerçeve içinde sınırlandıracak ve iktidar tarafından konulan kural ve normları içselleştirerek kendisini özneleştirecektir. Foucault'da özneleşme söylemleştirmeyle gerçekleşirken, Lacan'da dilin simgeler aracıllı̆ıyla gerçekleşir. Böylelikle, ikisi de sosyokültürel dinamikler üzerinden özneyi kurarken Foucault'da bu süreç, sadece daha politik gelişir. Örneğin, Foucault söyleminde deli ile akıllıyı ayıran 
bölücü pratikler, iktidar mekanizmalarıdır. Lacan anlatısında ise, insan benlik kazanıncaya kadar tüm nesne ve kişilerle bir bütünlük ilişkisi içindedir ve bölünme ise dil yoluyla gerçekleşir. Yani, dille kurulan özne her zaman dille bölünür, çünkü özne yaşadığı sürece bu bölünmüşlükten çıkamaz. Böylelikle, Foucault ve Lacan'da özneleşme süreçleri her ne kadar birbirinden farklı dinamikler ile gerçekleşse de, aslında her ikisinde de özne, dış güçler sayesinde kimlik kazanır. Dolayısıyla, özneleşme bir bakıma insan biçiminin tarihsel mutasyonlara uğradıktan sonra kimlik değiştirmesiyle ilintilidir.

Nitekim, bir varsayımda bulunursak, modernizmin diş güçleri sanayileşme, kentleşme ve kurumsallaşma; insana içkin özellikleri de bireyselleşme, özgürlük, homojenlik olarak düşünülebilir. Aynı şekilde postmodernizmin dış güçleri kitle iletişim araçları, kopya ve tekrar, kitle kültürü; insana içkin özellikleri de tüketim alışkanlığı, ortak beğeni, heterojenlik şeklinde ifade edilebilir. Dolayısıyla, modern insan ulusal bir kimlik kazanırken, postmodern insan kültürel bir kimlik kazanır. Yukarıda her iki dönemdeki dış güçlere dair örnekler, Foucault'nun dış güçleri toplumsal ve tarihsel oluşumların etkisi altında şekillenen iktidar mekanizmaları olarak tanımlaması üzerinden verilmiştir. Çünkü iktidar mekanizmalarının özellikle toplumda köklü değişiklikler meydana getirme gibi bir işlevi vardır. Modernizmdeki en büyük toplumsal yenilik ise, sanayileşmenin ihtiyaç duyduğu fiziksel gücün sağlanması amacıyla başlayan şehircilik hareketleridir. Dolayısıyla modernizmde toposa dair bir bilinç değişimi de yaşanır ve bu değişim, heterotopyanın etimolojik açılımının tekrar yapılmasını gerekli kılar. Şöyle ki kentleşme, Foucault'nun mezarlıkları gibi zaman içinde işlev değişikliğine uğrayan heterotopyalara örnek gösterilebilir. Çünkü tarihler boyunca doğayla iç içe idame ettirilen toplumsal yaşam kırsaldan koparılarak beton binalara taşınmıştır. İnsanın doğadan kopuşu, aynı zamanda insan varoluşu ve benliğinde yaşanan bir yabancılaşmaya da referans verir ve bu yabancılaşma ise çalışmanın giriş yazısında bahsedildiği üzere bebeğin plasentadan ayrılarak ilk defa toposla kurduğu ilişkideki yabancılaşmaya benzetilebilir. Belki de, Lacan'ın tanımlanması zor gerçeklik ilkesi, tam da burada devreye girmektedir. Doğanın bir parçası olan insanın kültürel kodlarla sistemin ögelerini içselleştirmesiyle artık doğaya karşı yabancılaşması, gerçekliğin Lacancı tabirle olmadığı ya da sadece kültürel bir gerçekliğin olduğu manasına gelebilir. Çünkü, modern bir dünyada hayata gelmiş bir çocuğun apartman dairesinde yaşaması onun kendi gerçekliği gibi algılansa da, ontolojik olarak çocuğun hala doğaya yönelim içinde olduğu ve doğadaki yaşam koşullarının elverişsizliğini kodlayan toplumsal normlarla bilinçdışında bunu bastırdığı düşünülebilir. Dolayısıyla topos, gerçek anlamda toprağı imleyen bir yer olarak tanımlanırken, bilinçdışına simgesel olarak gönderme yapan bir yer olarak da ifade edilebilir.

Topos, özellikle tarihsel avangardların ütopik dünya tasarılarında simgesel olarak önemli bir yer tutar. Örneğin, sürrealistler psişik otomatizm araçsallığında hayal ve fantezi dünyasını, akıl ve mantığın sıradan dünyasıyla ilişkilendirmeyi amaçlar. Bunun yanı sıra, marksist ve sosyalist düşünceden beslenen sürrealist avangardlar, hayatla sanatı entegre etme uğraşları doğrultusunda devrimci bir eğilim sergiler. Ancak, 1930'larda avangard sanat gündelik hayatın dönüştürülmesini benimserken, Andre Breton'un artık devrimci hareket içinde yer almadığını düşünen bazı sürrealistler, bu davayı devralarak sitüasyonizm çatısı altında sürdürmeye çalışır. Sitüasyonist Enternasyonal'in kurucu figürlerinden Guy Debord ise sürrealistlerin bilinçaltı odacıklarının mekanı ve zamanı tanımlamadaki arzu ve istenç mefhumlarının kitlesel tüketimi körükleyebileceğini ve böylece sanatın da metalaşacağını dile getirir. $\mathrm{Bu}$ yüzden de Debord, hayatı değiştirecek olan avangard sanatı rüyalarla tasavvur edilen ütopik sınırlardan ve mekanlardan kurtarmak ve salt gerçekliğe kavuşturmak ister. Dolayısıyla Debord öncülüğünde sitüasyonistler sosyal hayatı imleyen yeni kelimeler ve ifade biçimleri üretirler. Şöyle ki, sitüasyonist kavramı 'üniter bir çevrenin ve bir oyununun kolektif örgütü tarafından somut ve kasıtlı bir şekilde yapılandırılan bir hayat anı veya varedilmiş durumu' (Erdoğan, 2008, s. 19) olarak açıklanır. Bununla birlikte, Sitüasyonist Enternasyonal'in diğer iki önemli kavramı dérive ve psikocoğrafya'dır. Dérive kavramı sürrealizmde flanöre denk gelir. Ancak, flanör kenti amaçsızca, eylemsizce dolaşırken; derive, gözlemi kenti dönüştürme pratiği içinde gerçekleştirir. Yani, rastlantısal ve keyfi bir sanatsal deneyimden öte, siyasal bir eylemi gerektiren yapısıyla dérive, çelişkileri teşhir ederek ve alternatifleri sunarak haritaların arka planında kalan ve görülmesi öylece kolay olmayan kentsel unsurları 
dönüştürür. ${ }^{13}$ Sitüasyonist Enternasyonal sözlüğüne göre psikocoğrafya ise, kasten ya da bilinçsiz bir şekilde düzenlenmiş coğrafi koşulların, bireylerin duyguları ve davranışları üzerindeki özgül etkilerinin bir çalışması olarak tanımlanmaktadır (Covery, 2011, s. 78). Dolayısıyla, psikocoğrafya kentin toplumsal yapısıyla nesnel, kentin birey üzerinde bıraktığı izlerle de öznel bir pratik olarak karşımıza çıkar. Bununla birlikte psikocoğrafya, derive olmadan aktif olamaz, aynı durum derive için de geçerlidir, böylece bu iki kavram özne ve topos ikiliğinde çalışır.

Özne-topos diyalektiği ise Foucault'nun 'Heterotopya' kavramını hatıllatır. Çünkü Foucault, topos'a mekansal ve uzamsal farklı iki boyut katarak güç odaklarına dair bir bilinç kazandırır. Ancak Foucault özne ve iktidar kavramlarıyla sadece kontrol mekanizmalarının yarattı̆̆ toplumsal düzen ve yapıya işaret etmez. Çünkü siyaset ve bilgi rejimleri dışında toplumun kendi inşa ettiği birçok kültürel form ve etnografik unsur vardır ki Foucault bunları 'Heterotopya' olarak adlandırır. Derivelerin keşfettiği psikocoğrafya da, haritaların gösteremediği toplumsal yapının tüm yasaklarını, tabularını ve bazen de sınıf çatışmalarını, ekonomik savaşlarını ve kültürel değerlerini gerçek bir şekilde ortaya koyar ve Foucault'nun gerçekleşen ütopyalar olarak tanımladığı heterotopya, bu şekliyle psikocoğrafyanın realist tutumuyla oldukça özdeşleşir. Ayrıca psikocoğrafya kentleşmenin, sanayileşmenin, teknolojinin toposu labirentimsi çıkmaz sokaklara dönüştürmesiyle kurulan kaotik düzeni de eleştirir. İktidar mekanizmalarıyla ilişkili kurumsallaşma gösteren heterotopyalarda, bu eleştirel tavır, zaten en başından itibaren vardır. Bununla birlikte, psikocoğrafya ve heterotopyanın sözcük dizilimine bakıldığında her ikisi de iki sözcükten oluşur, tek tek sözcüklerine ayrıldıklarında ise semantik olarak her iki kavramın da sadece toplumsal bir eleştiri niteliğinde geliştirildiği düşünülür. Şöyle ki, psiko-coğrafya ve heterotopya'nın zaten anlamları gayet açı gibi görünse de, dönemin koşulları düşünüldüğünde postmodernizme yapılan incelikli göndermeler anlaşılır. Her iki kavramın da avangardların ütopik dünya tasarısıyla ve postmodernizmin çoğulculuk ilkesiyle ilintili bir şekilde öteki bir uzam ereğinde ortaya çıkarıldığı söylenebilir. Çünkü sitüasyonistlerle birlikte 1968 Mayıs Olayları'na destek veren isimler arasında Foucault'nun ve Lacan'ın da olması, bu savı doğrular niteliktedir.

Bilindiği üzere, 1968 Mayıs Olayları'nı fitilleyen birçok faklı dinamik söz konusu olmuştur: Cinsel eşitsizlikten işçi ve öğrenci haklarına, Cezayir sömürüsüne önayak olan Fransa'ya yönelik artan tepkilerden, ABD'nin Vietnam'a açtığı savaşa kadar çeşitli olaylardan rahatsızlık duyan ve endişe taşıyan birçok Avrupa ülkesinde protestolar düzenlenmiştir. Bu protesto ve gösterilere işçiler, öğrenciler, yazarlar, sanatçılar, aktivistler, filozoflar gibi toplumun her kesiminden insan katılmıştır. Böylece, birçok farklı sebeple bir araya gelerek oluşturulan düşünce ve kimlik çeşitliğinin dünya çapında bu denli yankı uyandırması 1968 ruhunun postmodernizmi başlatan etkenler arasında görülmesine neden olmuştur. Yani Lacan, Foucault veya Sitüasyonistler o dönem için farkında olmasalar da, dünya gerçekten değişmekte ve farklı özneler tesis etmekteydi. Dolayısıyla, modernizmin ulusal kimliği kültürel kimliğe evrilmekte, enformasyon çağı ise yavaş yavaş meyvelerini vermekteydi. Aslında Foucault'nun ve Lacan'ın sezinlediği ama tam olarak yaşamadan belki de ucundan yakalayabildiği bu yeni çağda Nietzche'nin üst-insanı veya Foucault'nun 'insanın ölümü' çoktan son bulmuştu.

Günümüzün rejeneratif dinamiklerinde ise artık teknoloji başrolü oynamaktadır. Modernizm ve postmodernizmin yaratmaya çalışı̆̆ı kimlikler yıkıma uğrarken belki de androjenleşme hükmünü ilan etmektedir ya da yeni insan biçimi, yapay zekanın aktif rol oynadığı transhuman veya posthumana evrilmektedir. Foucault'nun iktidar aygıtları da artık sosyal medya aracılığıyla görevini yerine getirirken $^{14}$, Lacan'ın benlik kuramı sanal gerçeklik içinde yeni bir boyut kazanmaktadır. Yeni

\footnotetext{
${ }^{13}$ Ali Artun, 21.05.2019 tarihinde Ankara Mimarlar Derneği’nde gerçekleştirdiği konuşmasında derive ve flanör arasındaki ayrıma dikkat çeker.

${ }^{14}$ Günümüzün en önemli iktidar aygıtlarından biri teknolojidir ve sosyal medya hesapları üzerinden bile bireyler tahakküm altına alınmaya çalışılmaktadır. Örneğin, Cambridge Analytica adlı bir araştırma şirketi, Trump'ın ve Brexit'in şeçim kampanyaları için çalışmış ve seçmenlerin sosyal medya hesapları üzerinden kişisel verilerine ulaşmıştır. Milyonlarca seçmeni çeşitli anket, bildirim ve özel mesajlarla manipüle ederek oylarını çalıştıkları adaylara vermeleri için yönlendirmişlerdir. Bununla birlikte, sosyal medya iktidar aygıtı olabildiği gibi heterotopya olarak da işlev görebilir. Çünkü kişi kendi isteğiyle simgesel (sanal) bir uzamda, yeni bir gerçek ben oluşturmakta ve onu içselleştirmektedir.
} 
heterotopyalar ise ağ-kentlerden örülü öteki bir uzam yaratırken, gerçek olmayan kimlikler sanal bir heterotopyada kendi yanılsamalarını yaşamaktadır.

Bilgilendirme/Acknowledgement:Bu çalışmada 2 Mayıs 2019 tarihinde http://web.mit.edu/allanmc/www/foucault1.pdf adresinden erişilen Foucault'nun heterotopyayla ilgili tek kapsamlı açıklama yaptığı 'Of Other Spaces: Utopias and Heterotopias' adlı İngilizce makalesinin Türkçe çevirisi tarafımca yapılarak makalede geçen bazı kavram ve kuramlar, Foucault felsefesine göre tanımlanmış ve yorumlanmıştır.

\section{KAYNAKÇA}

Akay, A. (2016). Michel Foucault'da iktidar ve direnme odakları. İstanbul: Doğu Batı Yayınları.

A. Artun (21.05.2019). 1968'in sanatı. Ankara: Ankara Mimarlar Derneği.

Artun, A. (2016). Sanat ve siyaset: Kültür çağında sanat ve kültürel politika. (5. Baskı), İstanbul: İletişim Yayınları.

Başer, N. (2012). Lacan. İstanbul: Say Yayınları.

Baudelaire, C. (2004). Modern hayatın ressamı. (Çev: Ali Berktay). İstanbul: İletişim Yayınları.

Covery, M. (2011). Psikocoğrafya: Londra yazıları. (Çev: Selen Serezli). İstanbul: Kalkedon Yayıncılık.

Erdoğan, Ş. (2008). Sitüasyonist enternasyonal. (Çev: Merve Darende, Melis Oflas, Artemis Günebakanl1). İstanbul: Altıkırkbeş Yayınları.

Foucault, M. (2016). Bilginin arkeolojisi. (Çev: Veli Urhan). İstanbul: Ayrıntı Yayınları.

Foucault, M. (2016). Bilme istenci üzerine dersler. (Çev: Kerem Eksen). İstanbul: İstanbul Bilgi Üniversitesi Yayınları.

Foucault, M. (2015). Büyük kapatılma, seçme yazılar 3. (Çev: Işık Ergüden ve Osman Akınhay). İstanbul: Ayrıntı Yayınları.

Foucault, M. (2007). Cinselliğin tarihi. (Çev: Hülya Uğur Tanrıöver). İstanbul: Ayrıntı Yayınları.

Foucault, M. (2011). Entelektüelin siyasi işlevi, seçme yazılar 1. (Çev: Işık Ergüden ve Osman Akınhay ve Ferda Keskin). İstanbul: Ayrıntı Yayınları.

Foucault, M. (2016). Güvenlik, toprak, nüfus. (Çev: Ferhat Taylan). İstanbul: İstanbul Bilgi Üniversitesi Yayınları.

Foucault, M. (2001). Kelimeler ve şeyler. (Çev: Mehmet Ali Kılıçbay). İstanbul: İmge Kitabevi Yayınlar1.

Foucault, M. (1984). Of other spaces: Utopias and heterotopias: 2 May1s 2019 tarihinde http://web.mit.edu/allanmc/www/foucault1.pdf adresinden erişildi.

Foucault, M. (2017). Öznellik ve hakikat. (Çev: Sibel Yardımc1). İstanbul: İstanbul Bilgi Üniversitesi Yayınlar1.

Foucault, M. (2014). Özne ve iktidar, seçme yazılar 2. (Çev: Işık Ergüden ve Osman Akınhay). İstanbul: Ayrıntı Yayınları.

Foucault, M. (2018). Toplumu savunmak gerekir. (Çev: Şehsuvar Aktaş). İstanbul: Yapı Kredi Yayınları. 
Jain, D. (2014). Özgürleşme makineleri: Deleuze ve Marx. (Çev: Aslı İkizoğlu). İstanbul: Otonom Yayincilik.

Lacan, J. (2017). Babanın adları. (Çev: Murat Erşen). İstanbul: MonoKL Yayınları.

May, T. (2017). Deleuze: Bir birey nasıl yaşayabilir?. (Çev: Sercan Çalcı). İstanbul: Kolektif Kitap.

Platon. (2010). Devlet. İstanbul: Türkiye İş Bankası Kültür Yayınları.

Selvi, Y. (2014). Heterotopya üzerine görsel çözümlemeler. Yayınlanmamış sanatta yeterlik tezi. Gazi Üniversitesi Güzel Sanatlar Enstitüsü, Ankara.

Simmel, G. (2017). Modern kültürde çatışma. (Genişletilmiş 11. Baskı). (Çev: Tanıl Bora, Utku Özmakas, Nazile Kalaycı, Elçin Gen). İstanbul: İletişim Yayınları.

Tıbbi Terimler Sözlüğ̈̈. 2 Mayıs 2019 tarihinde https://saglik.sozlugu.org/heterotopia/ adresinden erișildi.

Toprak, İ. (2018). Zamansallı ve mekansallık bağlamında heterotopyaların sentantik ve semantik irdelenmesi. Yayınlanmamış doktora tezi. İstanbul Teknik Üniversitesi Fen Bilimleri Enstitüsü, İstanbul.

Zourabichvili, F. (2011). Deleuze sözlüğ̈̈. (Çev: Aziz Ufuk Kılıç). İstanbul: Say Yayınları. 